\title{
Depictions of the Deep: Illustrations in the Popular Press of Deep-Sea Animals from Jules Verne (1860's) to William Beebe (1930's) and beyond
}

\section{Portrait des eaux profondes : Évolution des illustrations d'animaux des profondeurs dans la presse populaire, de Jules Verne (1860) à William Beebe (1930) jusqu'aujourd'hui}

\author{
John R. Dolan ${ }^{1}$ \\ ${ }^{1}$ Sorbonne Université, CNRS, Laboratoire d'Océanographie de Villefranche-sur-Mer, Station Zoologique, 06230 \\ Villefranche-sur-Mar, France, dolan@obs-vlfr.fr
}

Publié le 19 février 2020 DOI : 10.21494/ISTE.OP.2020.0475

\begin{abstract}
Our vision of deep-sea life changed dramatically with the results of scientific explorations and study of the deep that began in the 1860's. Mythical monsters, epitomized by Jules Verne's giant octopus, gave way to mysterious landscapes inhabited by odd creatures actually dredged up from the deep. While we now know of the diversity and unusual life cycles of deep-sea creatures, visions of the deep as a world of monstrous creatures persists today in the popular press.

KEYWORDS. scientific illustrations, popular press, oceanography, deep-sea exploration, history of science, history of oceanography, marine biology.
\end{abstract}

\section{Introduction}

Here are shown, in five 'chapters', changes in the depictions of deep-sea life in popular books and magazines. The time period covered is from the era of Jules Verne (1860's) to that of William Beebe (1930's) and to recent years. The major focus is on the period of the 1860's to the 1930's as it corresponds, firstly with early scientific exploration of the deep-sea, and secondly, growth in our knowledge of natural history of organisms in the deep-sea. Traditionally images such as those illustrating "20,000 Leagues under Sea" (and before) were of mythical monsters in the deep sea. With the first scientific explorations of the deep sea, from the 1860's - 1920's, the existence of odd creatures became known. The deep-sea was then depicted as an eerie land of monstrous forms but about which little was known. Finally with the first systematic studies, including in situ observations by William Beebe, some of the natural history of deep-sea organisms became known. Organisms were then shown with their predator-prey relationships and depictions of life-cycle stages of deepsea animals appeared. From the eras of Jules Verne to that of William Beebe, the imaginary monsters of the deep were gradually replaced by actual animals but of many with frightening shapes and unimaginable life cycles. Nonetheless, ferocious-looking and monstrous forms of the deep-sea still remain popular in contemporary works. 


\section{Jules Verne's 1860's: Mythical Giants ruled the Deep in the Popular Press}
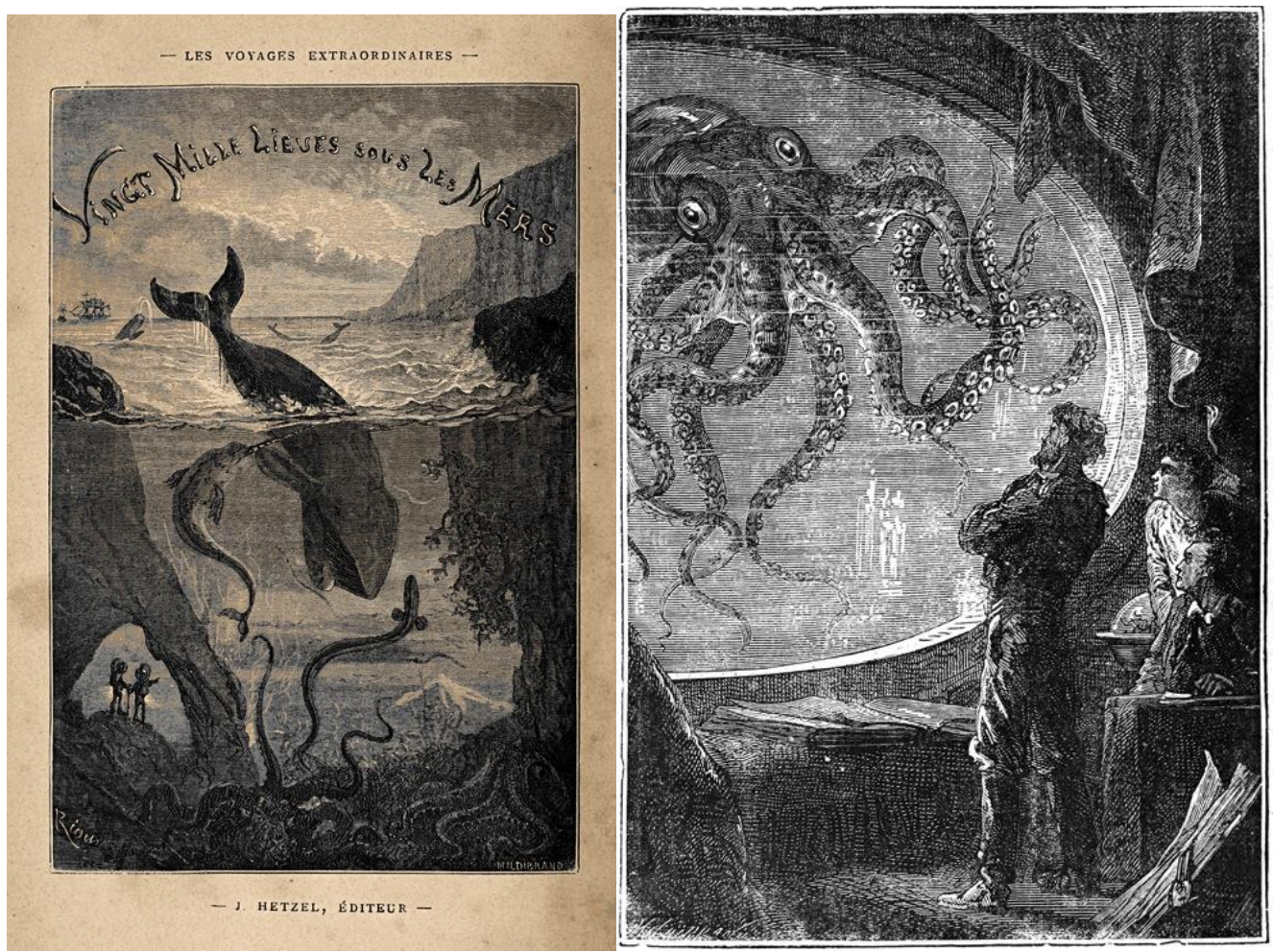

1869. Left Panel: Jules Verne's "20,000 leagues Under the Sea", the frontispiece in first edition 1869 showing sea serpents, giant narwhals and octopus observed by deep-sea divers. Right Panel: Captain Nemo admiring a giant octopus. Illustrations by Édouard Riou. The inspiration for Nemo's encounter is said to have been inspired by the "Calmar de Bouyer" alleged event of 1861 in which a giant squid was captured (below).

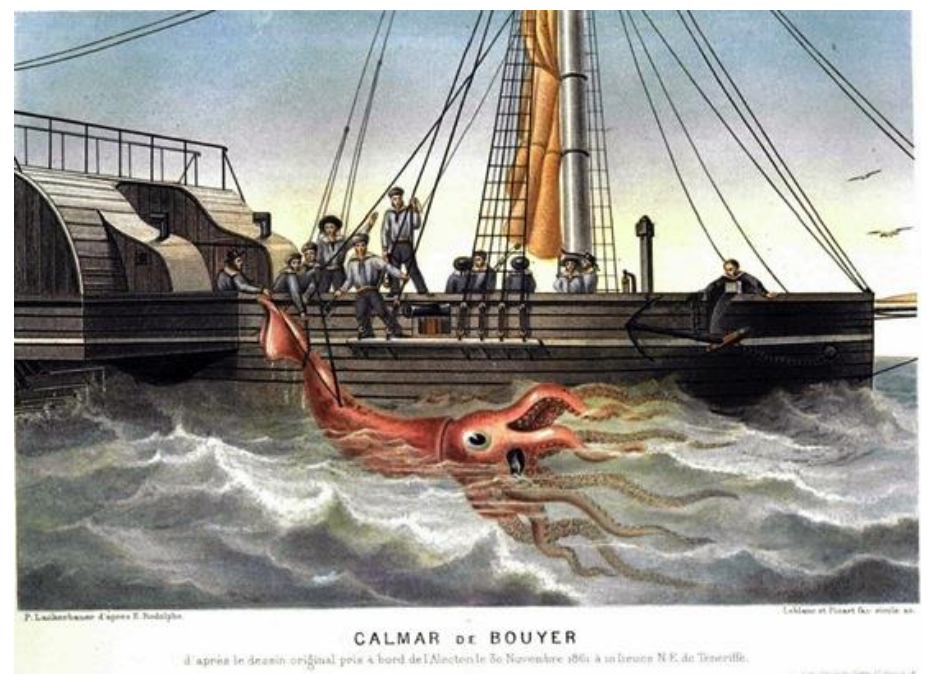

1865. "Le Monde de la Mer" (Frédol 1865) contained an illustration of an alleged "1861 event": the capture of a giant squid by the crew of the French steamer Alecon, near Cayene. Illustration by P. Lackerbauer. The event, doubted by Frédol, included killing the squid by firing several canon balls into it. The images of this event are said to have inspired Jules Verne (Hatcher \& Battey 2013). The giant deep-sea creatures in Jules Verne's book were commonly thought to exist in the 1860's despite the dominant scientific view that life was not possible at great depth. Images of giant creatures from the deep attacking ships have a long history as shown below. 


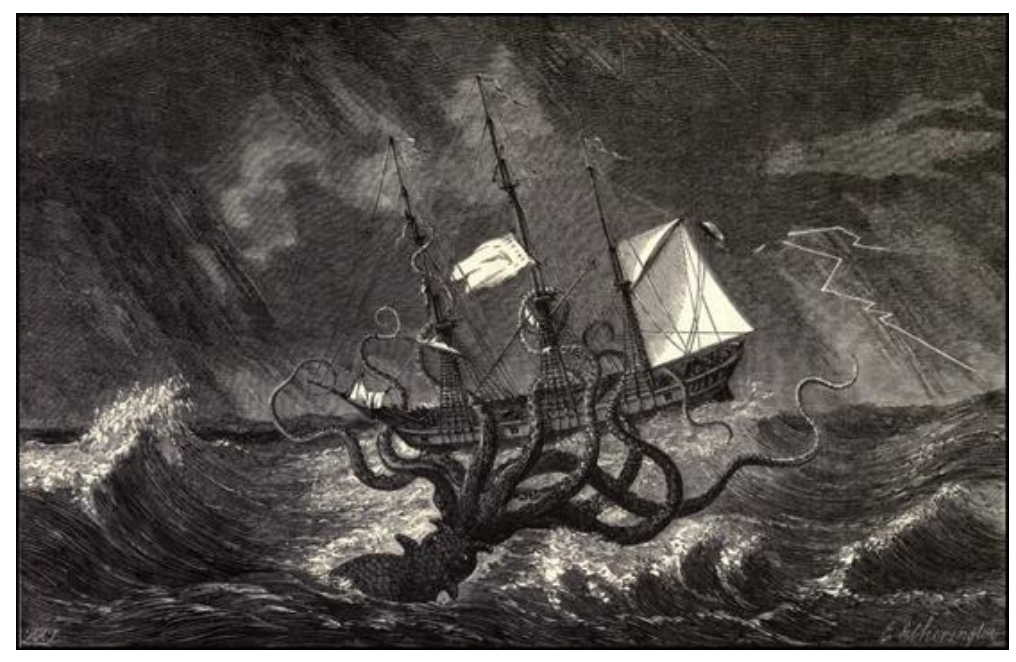

1868. An illustration of the "Kraken" - the mythical deep-sea creature attacking a ship during a storm at sea. Illustration by E. Etherington. From Mangin's 1868 "Les Mystères de l'Océan". Mangin detailed the long existence of Kraken stories.

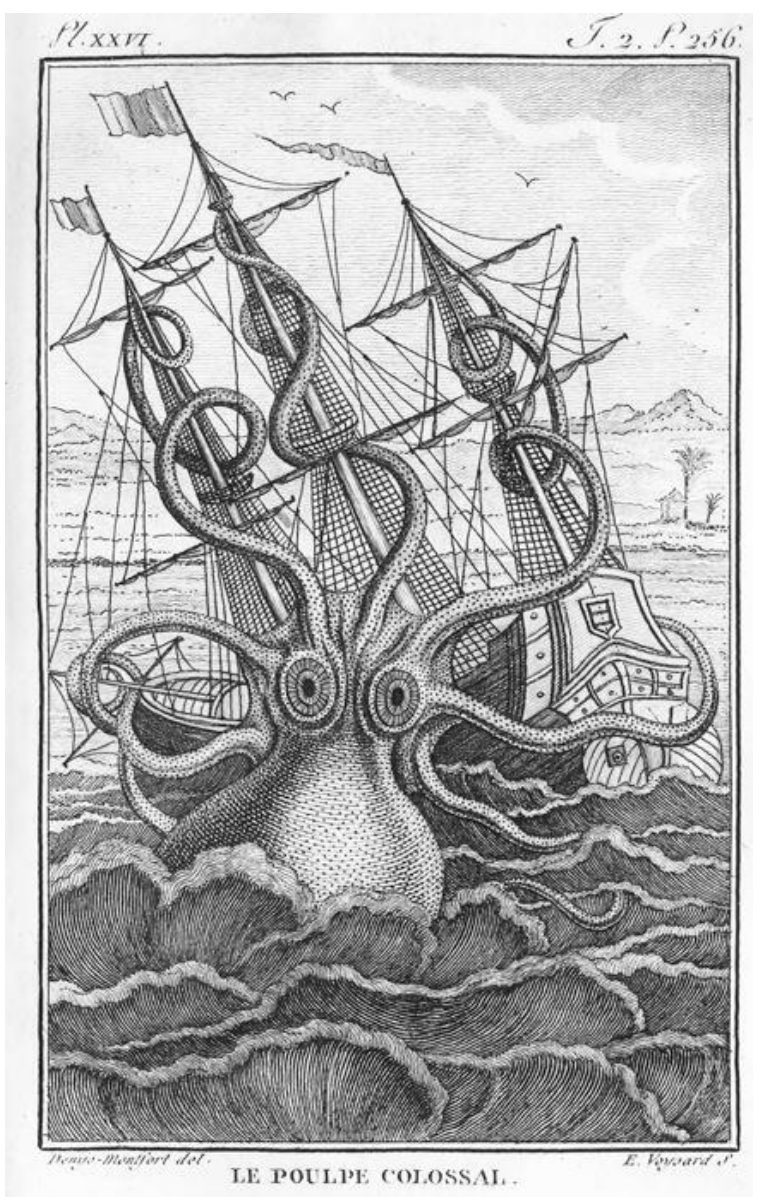

1802. The first "scientific description" of a giant cephalopod: Le Pouple Colossal (Giant Octopus) from Denys-Monfort (1802). Illustration by P. Denys-Monfort. Today it is considered no more than an imagined deep-sea monster based on Denys-Monfort's finding a large tentacle, likely from a deep-sea squid. 
II. Early Scientific Explorations of the Deep-Sea 1862- 1900: Existence of life and strange creatures at great depths revealed

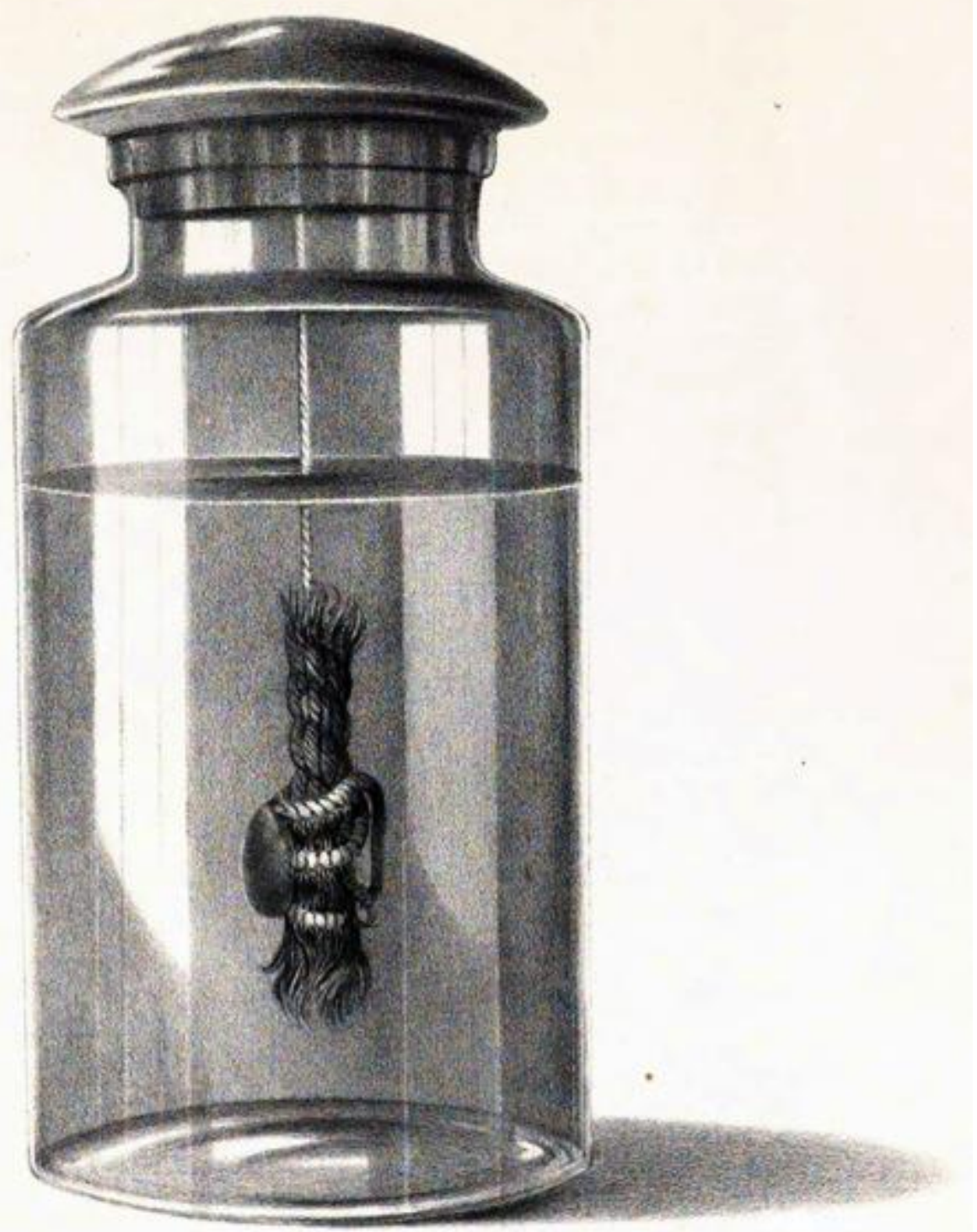

1862. This sketch of a brittlestar wrapped around of piece of sounding rope is likely the first image of a deep-sea creature (from $2000 \mathrm{~m}$ depth) brought up alive, from Wallich 1862, Plate I. Illustration by G.C. Wallich. About the same time that 20,000 Leagues was being written, the first deep-sea explorations were underway. Early observations of deep-sea creatures were of organisms on telegraph cable brought up from deep water for repair (e.g. Milne-Edwards 1861) dispelling the dominant scientific notion of the time that life was not possible at great depth (i.e., Forbes 1844). One of the early expeditions to determine the suitability of the sea-bed characteristics for laying telegraph cables was an expedition of the British ship H.M.S. Bulldog sounding between Great Britain and Canada in 1860. During the sounding operations, living deep-sea animals were brought up, seastars - having attached themselves to the ropes dragged along the sea bottom. The image above is from Wallich's 1862 account of the Bulldog expedition. He found deep-sea forms that resembled those known from shallow waters, not monsters of any sort. 


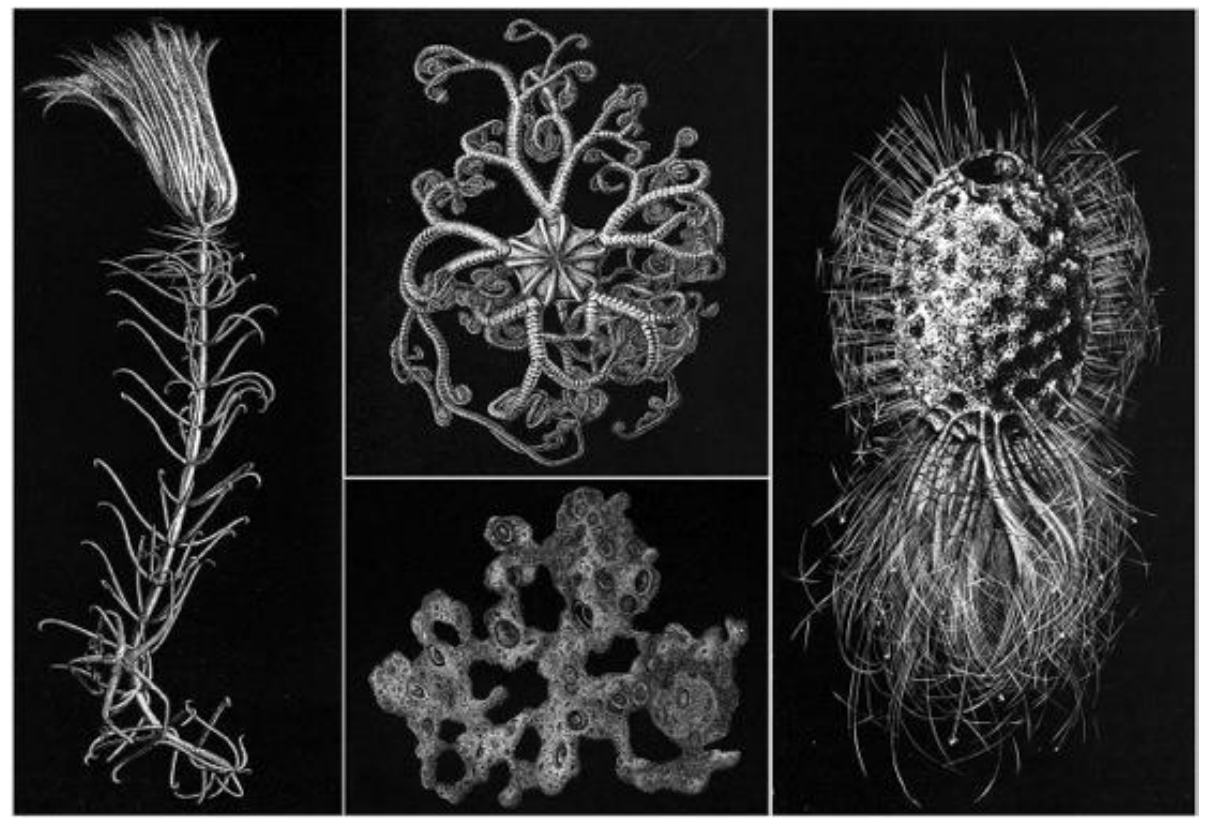

1873. Following soon after the explorations of the Bulldog were the voyages of the Porcupine and Lightening made famous in Thompson's 1873 book: "The depths of the Sea". While the Bulldog expedition was a submarine survey seeking information for laying a telegraph cable, the Porcupine and Lightning expeditions were specifically focused on collecting deep-sea life. The book's illustrations of novel organisms in the dark sea, on a black background, were striking and the first use of white on a black background. Illustrations by J. Wild. The organisms shown above appeared as 4 separate illustrations. At the left, a stalked crinoid (relative of a seastar), top center is a brittlestar much like the one retrieved on a sounding rope from the Bulldog expedition, the bottom center shows a microscopic amorphous mass "Bathybius", thought to be a primordial life form, a few years later revealed to be an inert chemical precipitate (Rehbock 1975), and at the left, a deepsea sponge skeleton.

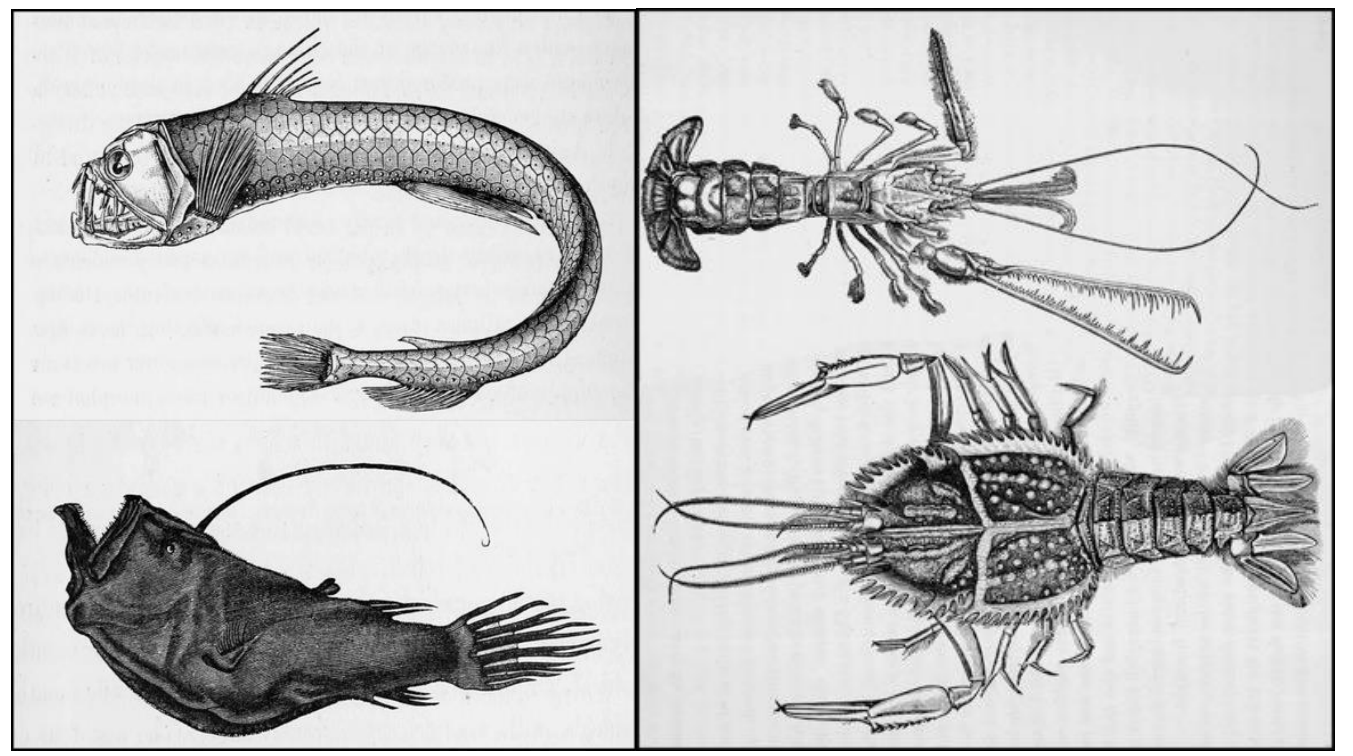

1877. The results from the Porcupine and Lightning revealing the existence of deep-sea life, motivated in large part the organization of the Challenger Expedition (1873-1876), the first globalscale oceanographic expedition (Bailey 1953). The 3-year voyage eventually yielded a massive series of 50 volumes composed of over 80 monographs published from 1885 to 1889 . The illustrations above, from the Preliminary Report by C.W. Thompson in 1878, showed ferocious fish, 
monstrous, but small (left panel) and showed armored prawns, perhaps monstrous, but also small. Illustrations by J. Wild.



1877. Another illustration from the Preliminary Report by C.W. Thompson in 1878 showed tiny jewels of the deep sea - "Challengerids", protists of the microzooplankton, he named them (all about $200 \mu \mathrm{m}$ in size) for the ship, the Challenger. Illustrations by J. Wild.

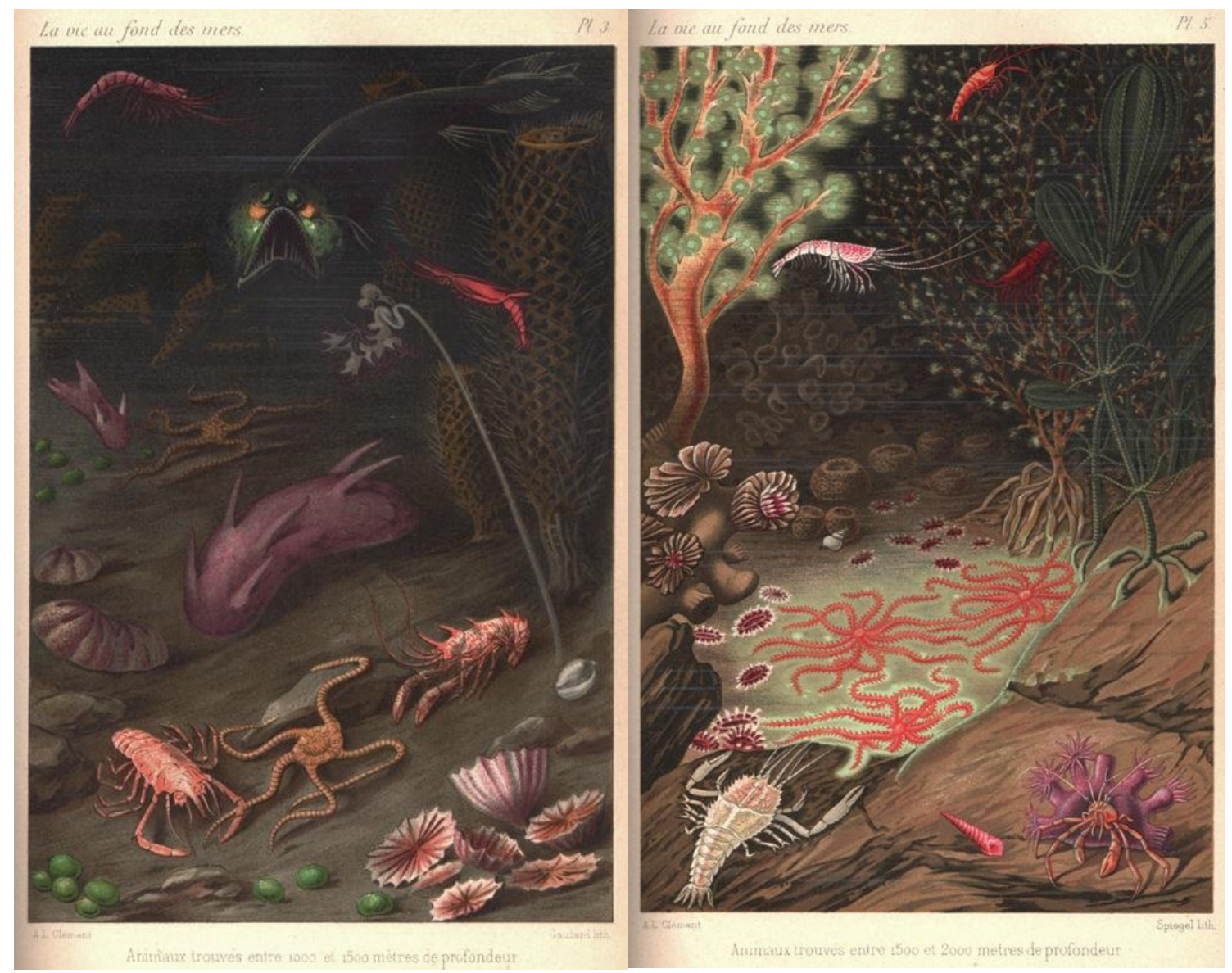

1885. The first French oceanographic expedition was the expedition of the Travailleur in 1880 (Rice 1980). In 1885 Filhol published "La Vie au Fonds des Mers: Les explorations sous-marines et les voyages $d u$ Travailleur et du Talisman". Left Panel: Animals of the deep sea shown in an eerie landscape. Right Panel: a fantastic, garden-like seascape. Illustrations by A.L. Clément. 


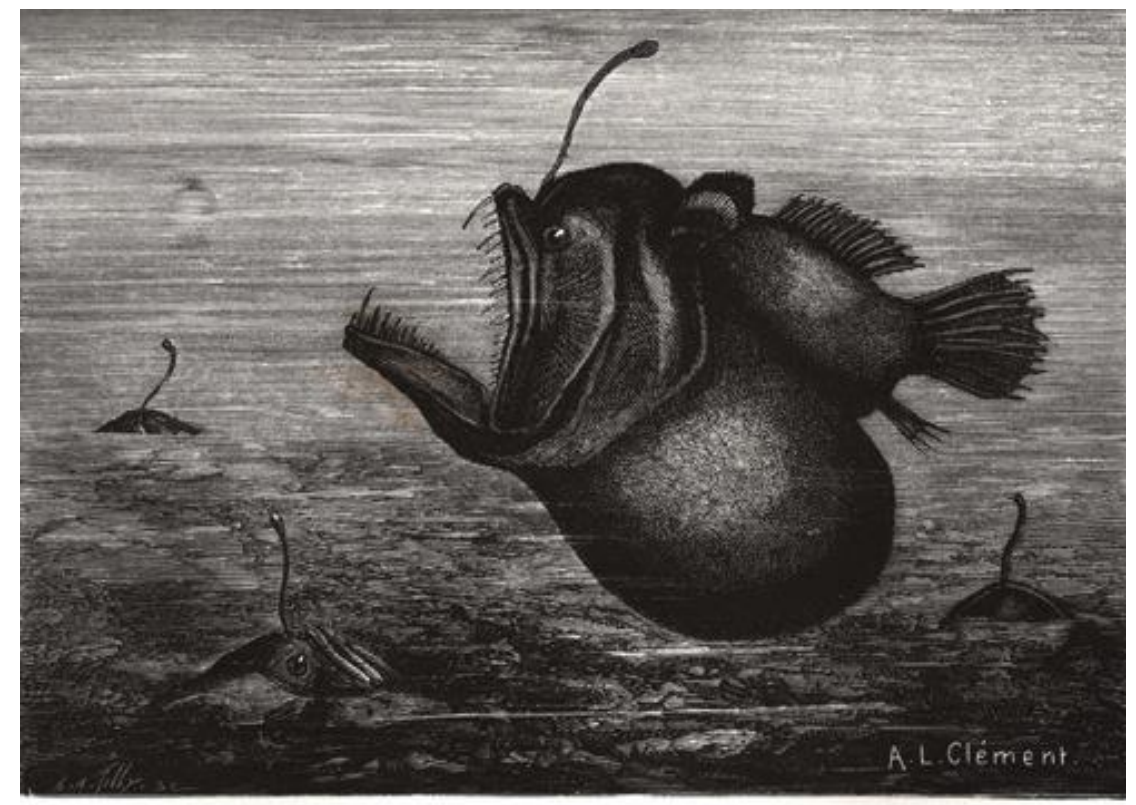

Fig. 27. - Melanocetus Johnstoui (Genth.), Moitió de grandeur aaturelle.

1885. A sea of fierce anglerfish from Filhol "La Vie au Fonds des Mers: Les explorations sousmarines et les voyages du Travailleur et du Talisman". Illustration by A.L. Clément.

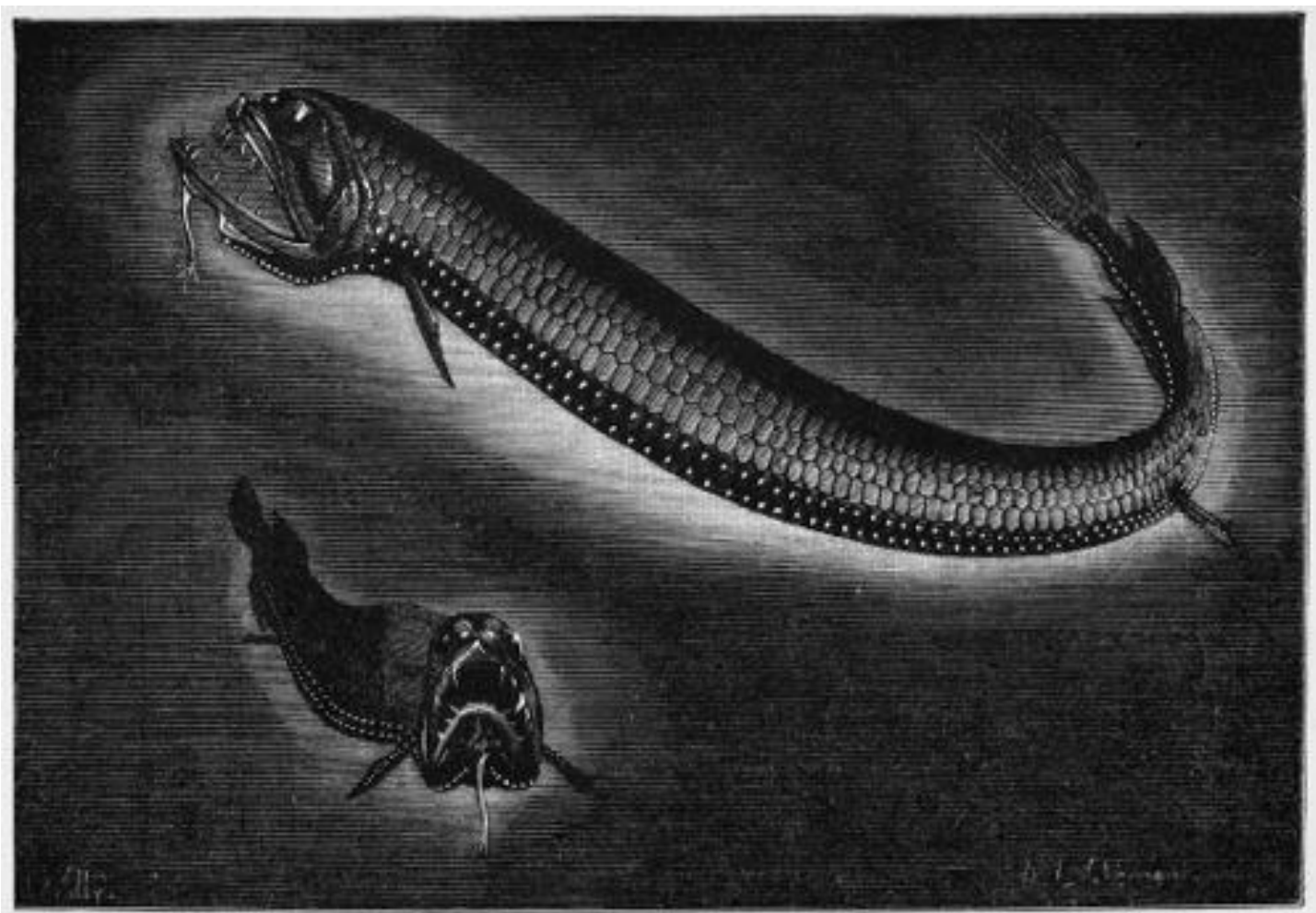

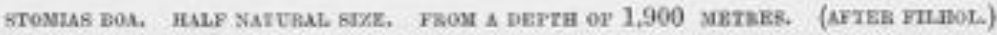

1894. By 1894 some of Filhol's images of scary fish mages were becoming wide-spread appearing in other books such as Hickson's book "Fauna of the Deep" published in 1894. Illustration by A.L. Clément. 
III. Early Modern Period 1900 - 1928: Actual deep-sea creatures appear in not only in books but also newspapers and magazines

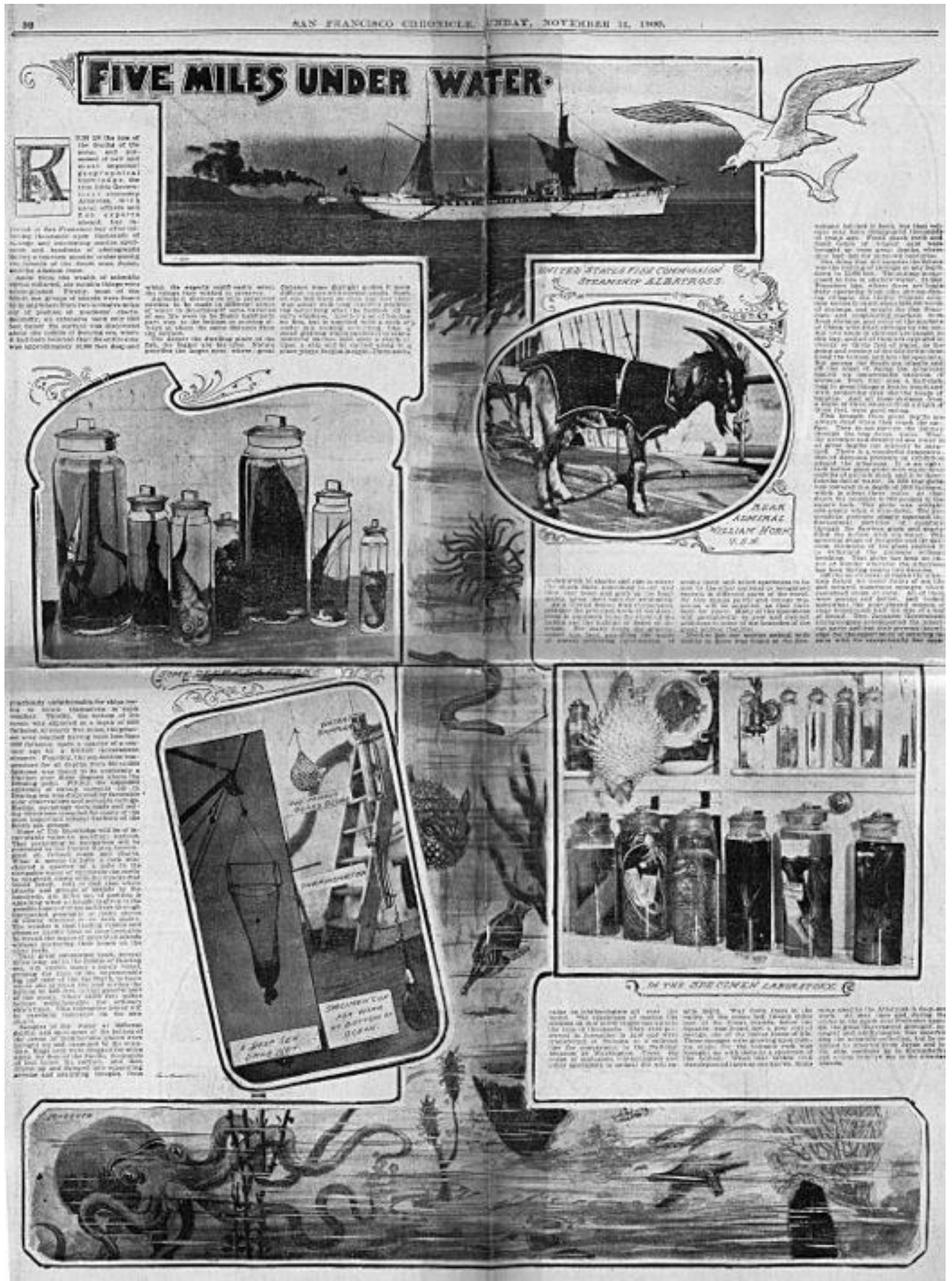

1900. The San Francisco Chronicle reporting on the findings of the Albatross explorations of the deep Pacific. Pictured were preserved odd deep-sea fish but note that a deep-sea octopus still decorated the view of the deep sea. Illustration by L. Anguth. 


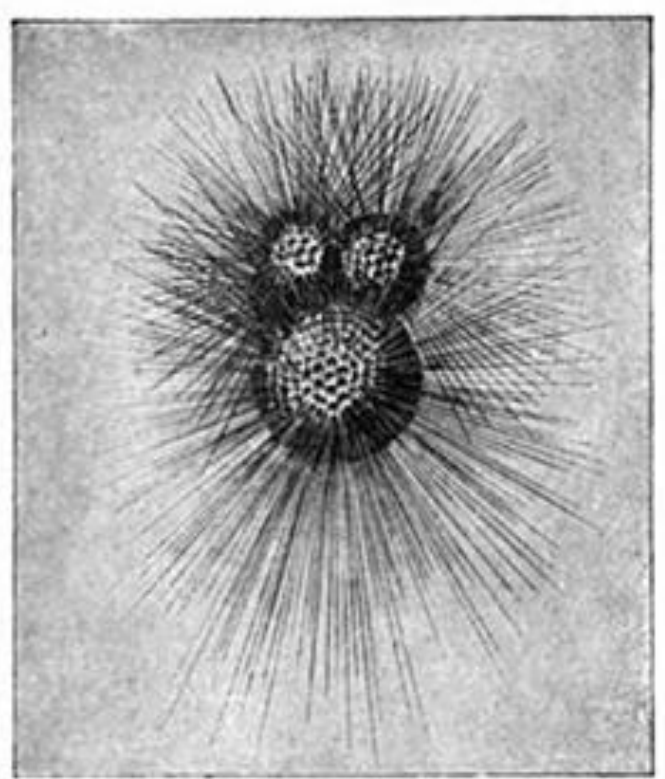

tively upon the character of the surface life prevailing above them.

Beyond these, in the deeper parts of the ocean, we find the red clay deposits, which cover about half the ocean floor. This region is not affected by material from the land, and receives little matter from the surface belt. It lies so deep that the shells of pelagic organisms falling down are removed through the solvent action of the deep water. The red clay is believed to have formed slowly, not more than a few feet of matter having accumulated since the Tertiary period.

Exploring in the mid-Pacific basins, the Albatross encountered many wide areas nearly destitute of animal life, but covered almost entirely by mineral deposits, principally manganese. The detailed study of. marine deposits will help to solve mysteries in the evolution of the continental and



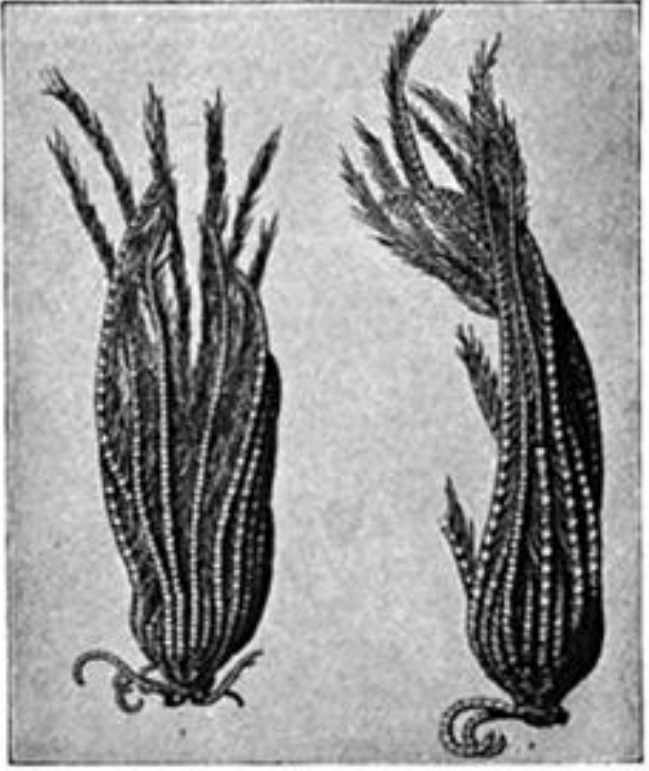

At the tep are Ririsa Fonaminifore ; Lelour, Crinoddo, or Sirg. Wies (animats, not plontor). oceanic areas. Plant life has not been found in great depths, and marine vegetation exists along the shore region, and only down as far as sunlight can penetrate.

From the evidence now at hand with respect to light in the sea, it seems certain that the sunlight does not extend below a couple of hundred fathoms, and even there becomes very dim. Below this the vast body of the ocean is absolutely dark. The brilliantly colored and abundant surface life is not found here, and the whole region is devoid of animals, except for the sinking through it of the calcareous remnants of those which have died at the surface. This is the intermediate and probably lifeless belt.

The abyseal region at the bottom is illuminated only where there are animals, in which case the light is phosphorescent. It has the actinic property of rendering conspicuous the reds, yellows, and greens which predominate among deep-sea animals. Dredg-

1902. From an article in "Everybody's Magazine" by C.H. Townsend: "Life in the Deep Sea", also on the Albatross expeditions. Note that that non- monstrous organisms, a microscopic foraminifera (top) and a flower-like crinoid (bottom) were shown along with the Gulper Eel. The unattributed illustrations were likely those of J. Wild. 


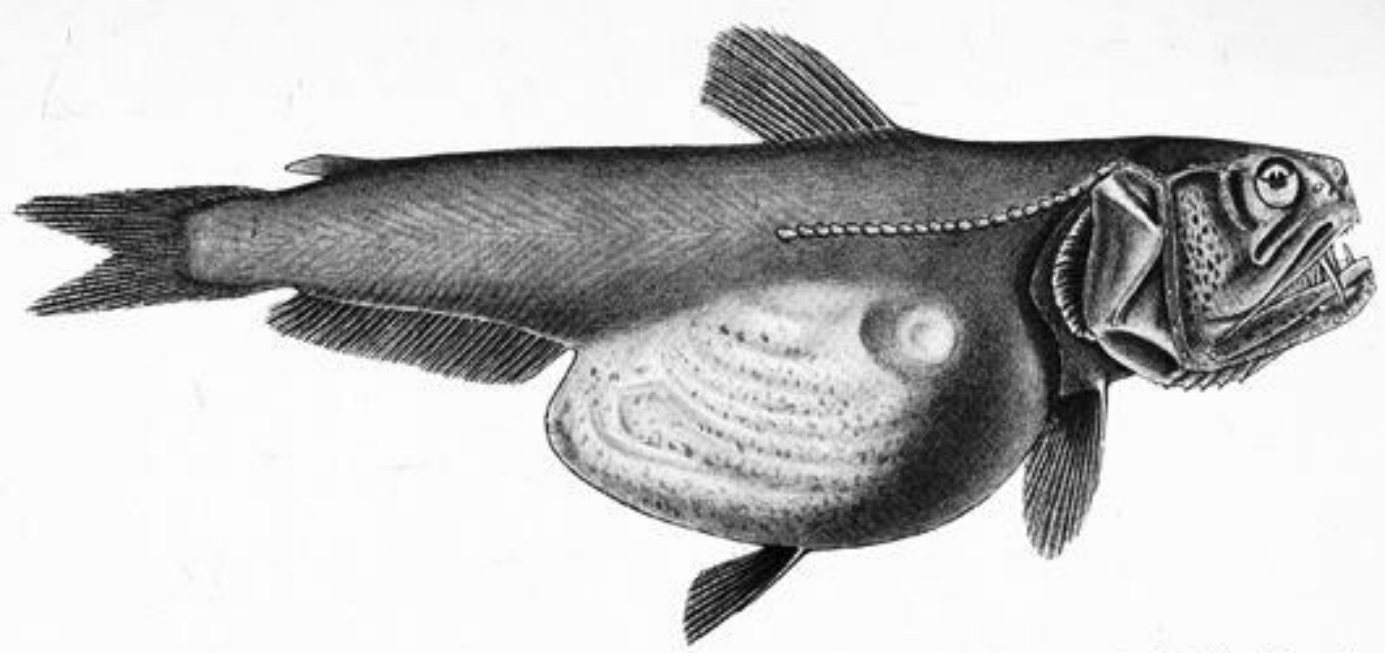

Fig, 43,- Oloutoutomus atrutus, from the Bay of Bengal and Andaman Sea, 573-870 fathoms. The individual figured, which is an immature specimen enlarged, bas swallowed a cuttlefish much broader than itself; the eyes and tentacles of the cuttle-fish being visible through the divtended abdominal wall of the gorger.

1902. "The Way of a Deep-Sea Fish". Illustration by A. Alcock. Perhaps the first depiction of the natural history of a deep-sea fish, as it shows what it ate, a squid larger than itself. From Alcott's 1902 book, "A Naturalist in Indian Seas"

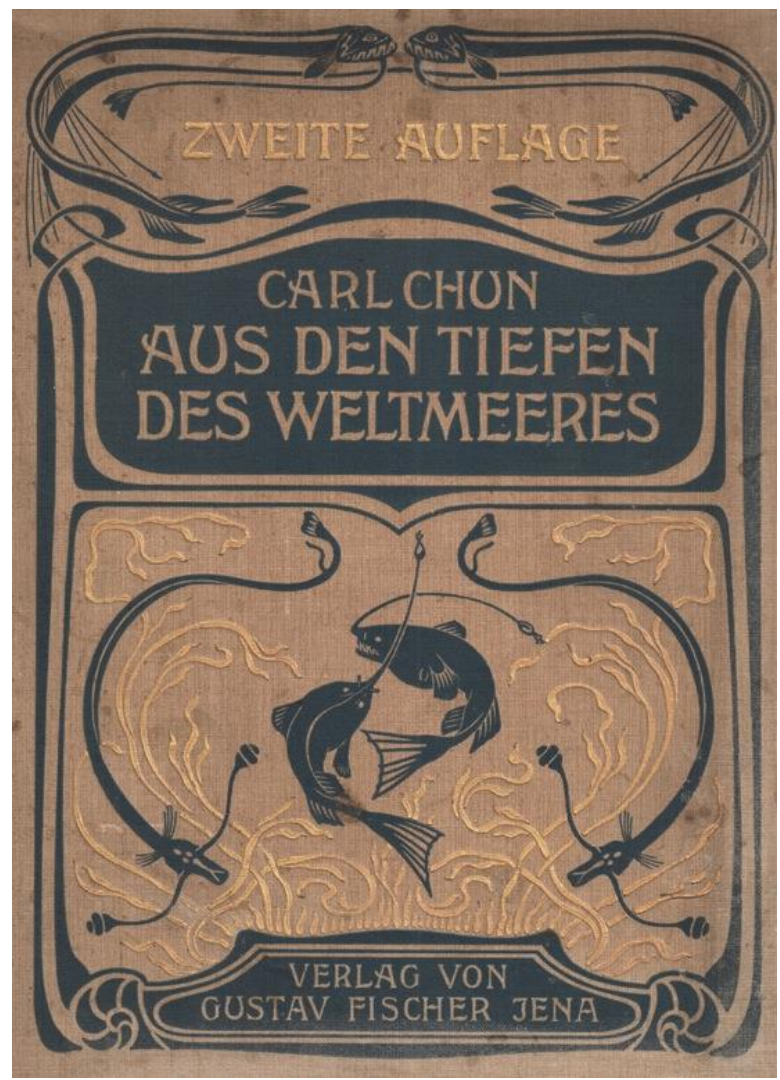

1903. The cover of Chun's popular book on the 1901 Valdivia Expedition was decorated with the strange shapes of deep-sea fish. The Valdivia Expedition was the first large-scale (global) devoted to investigation of deep-sea life. Cover artwork not attributed. 

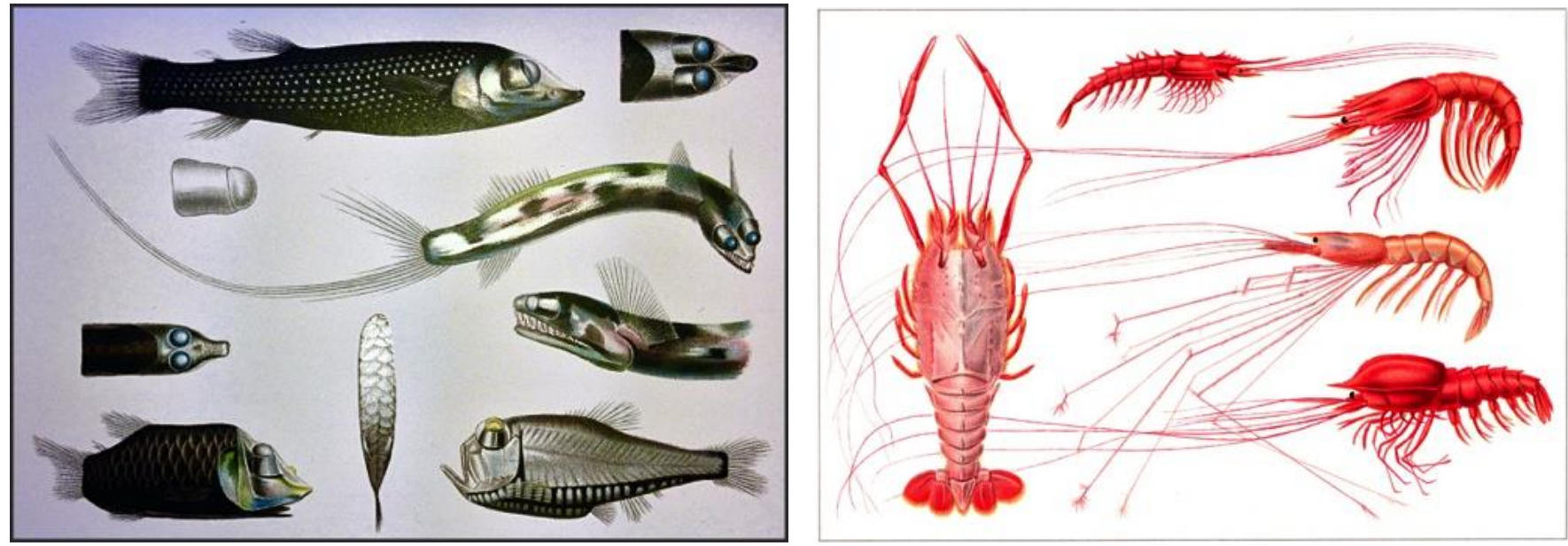

1903. From Carl Chun's popular book (1903) on the Valdivia Expedition. More deep-sea oddities from the first large-scale oceanographic expedition dedicated to deep-sea exploration, the Valdivia Deep-Sea Expedition. Illustration by F. Winter.

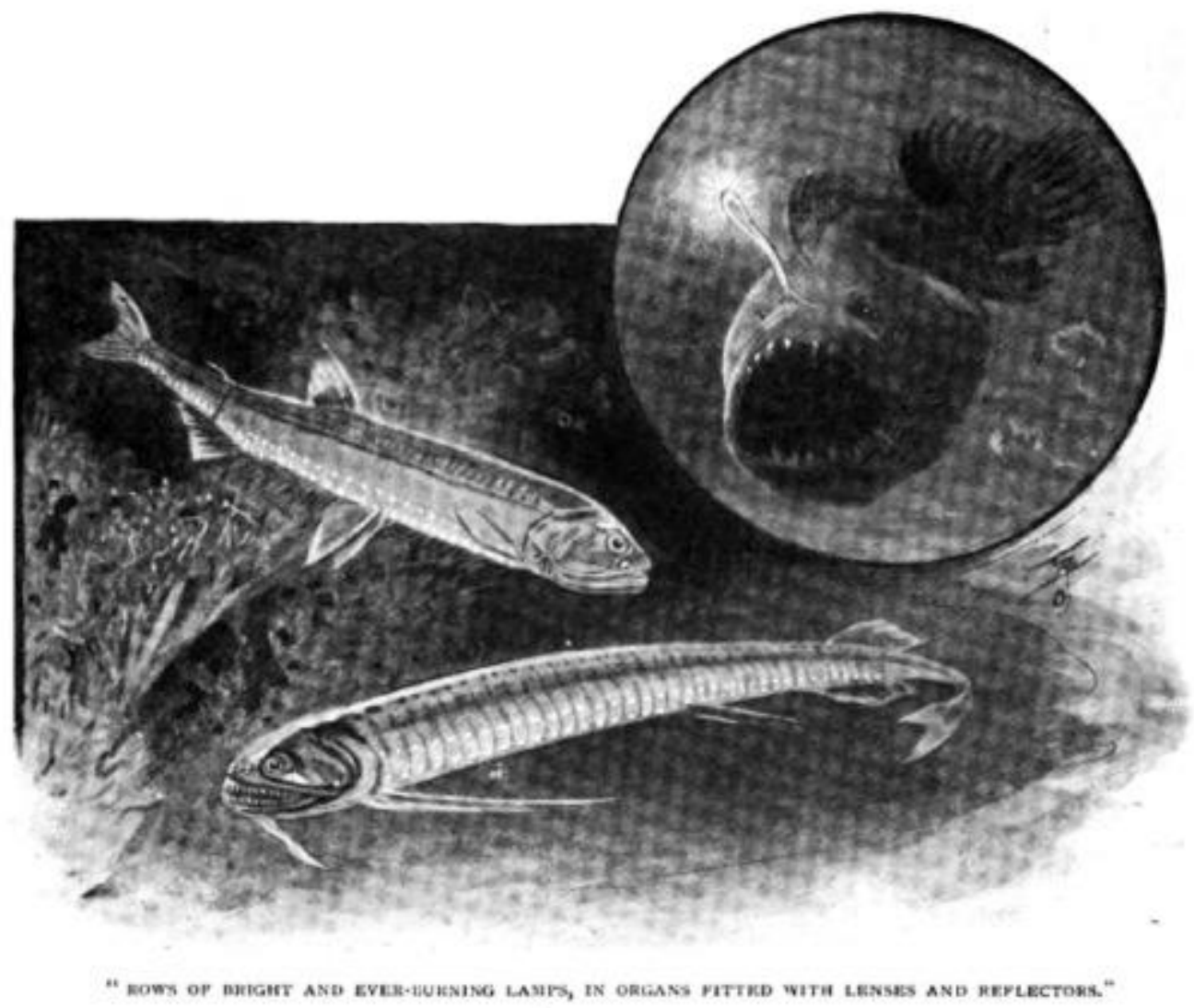

1904. The mysterious view of the deep-sea persisted. From a Strand Magazine article by C.J. Cornish "Living Lamps on Land and Sea" on bioluminescent creatures. Note that 2 of the 3 forms of deep-sea fish shown are fearsome. Illustration not attributed. 


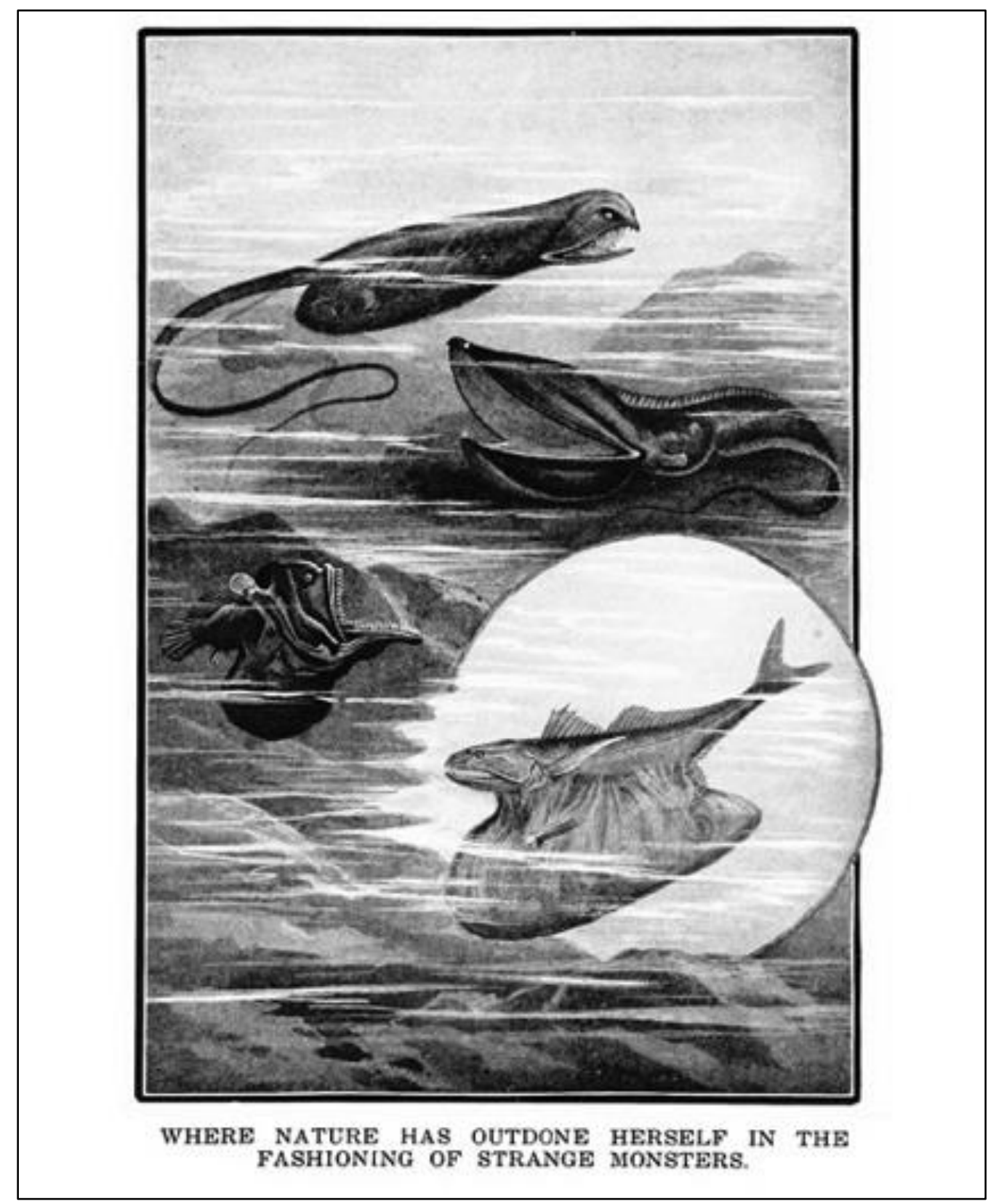

1904. Bullen's popular book "Denizens of the Deep" showing actual fish described as "strange monsters", then known to exist and shown fearsome, in an eerie landscape. Illustration by C.L. Bull. 


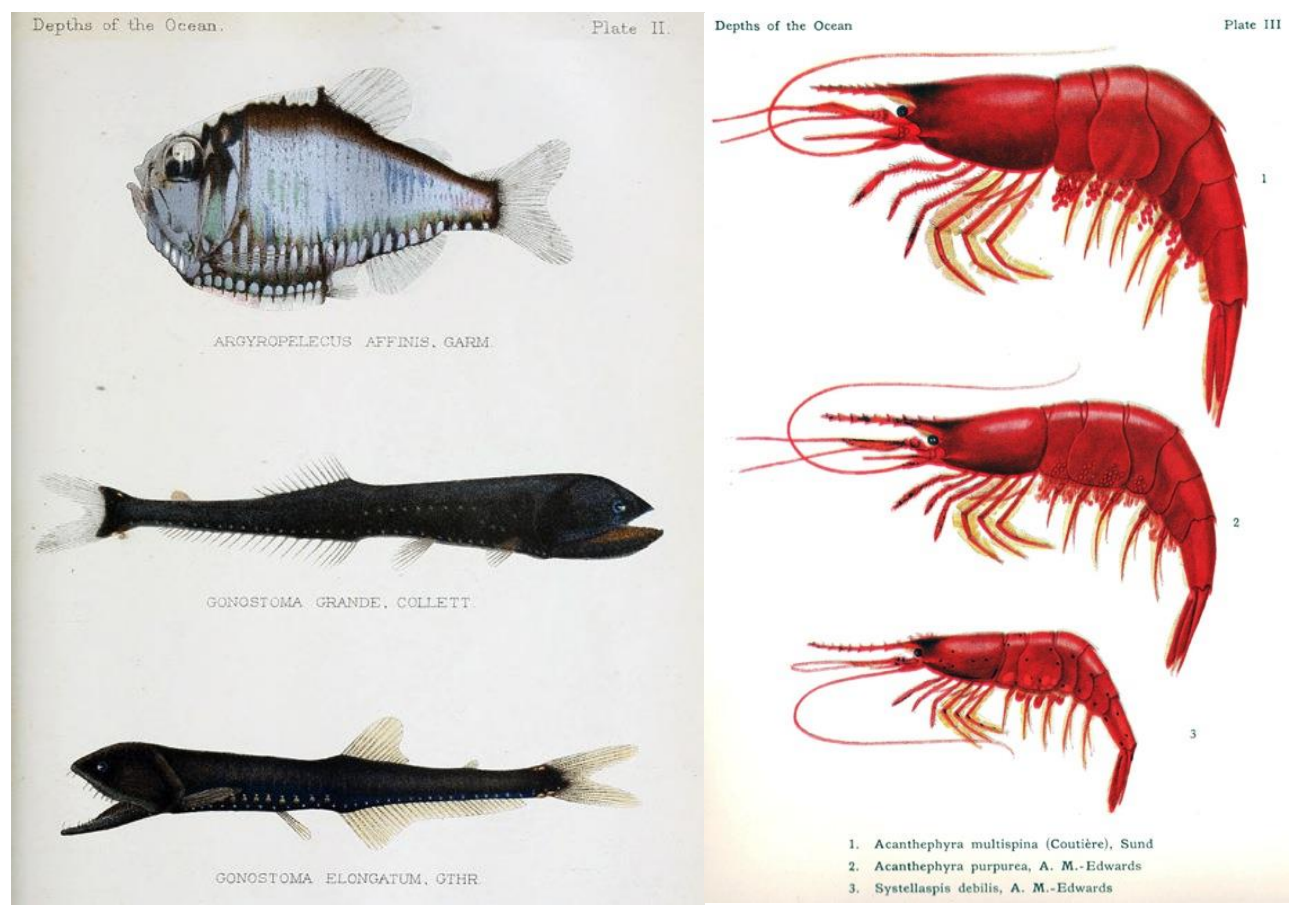

1912. Illustrations of scary fish and bright red shrimp in the second large-scale expedition dedicated to deep-sea explorations in 1910, from Murray and Hjort (1912) on Michael Sars Expedition in the North Atlantic in their book "The Depths of the Ocean". Illustrations not attributed.

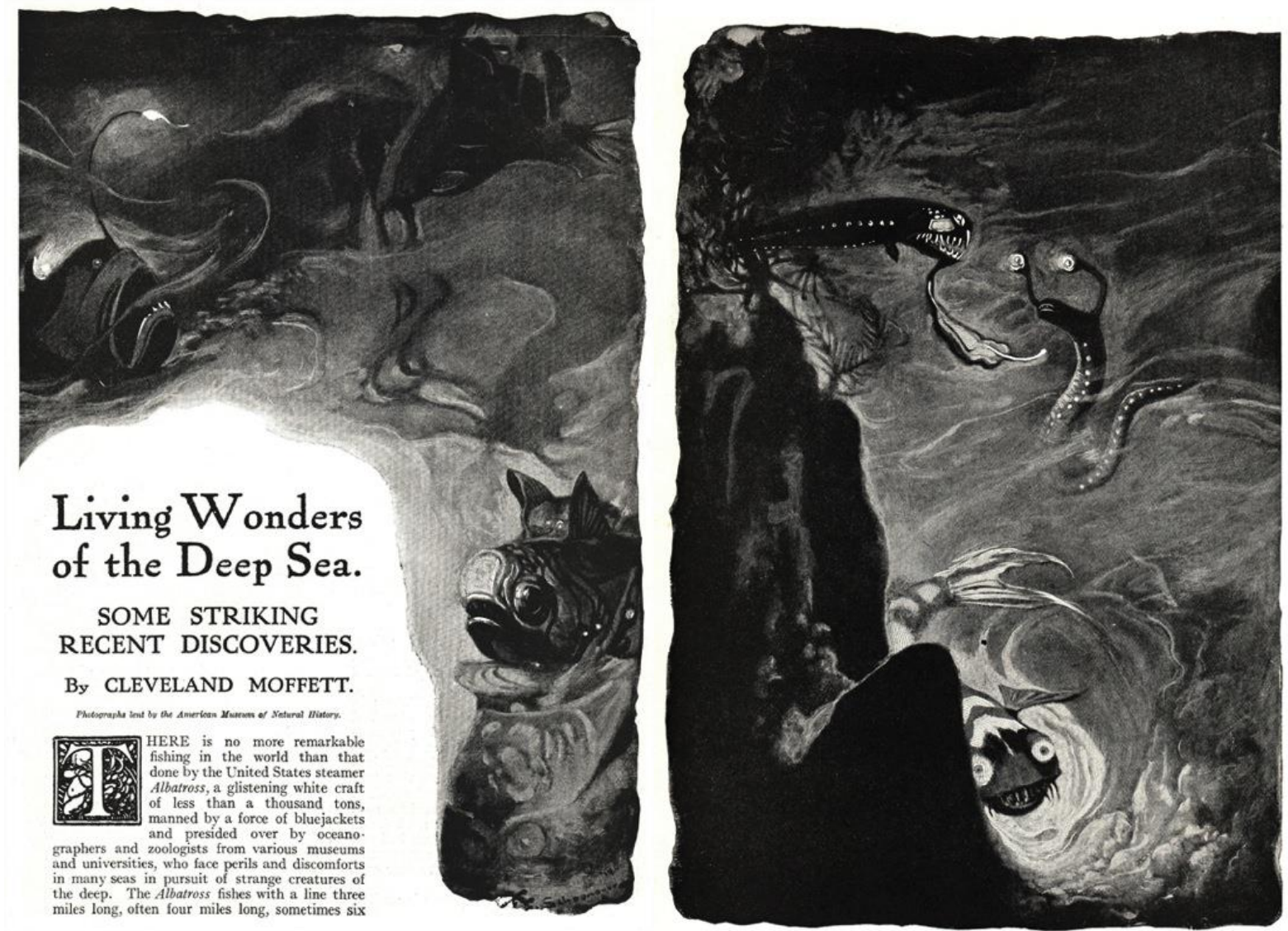

1915. By Cleveland Moffett in Strand Magazine. Still showing deep-sea as full of Anglerfish and monstrous forms. The artistic images of bizarre fish were based on actual reports from the Albatross Expedition. Illustrations not attributed. 




1922. An illustration from the book "Haunts of Life" by J.A. Thomson. As the ship dredging is a steamer, it is possibly the Albatross. Note the often-shown gulper eel, and the fish with stalked eyes (also on the cover of Chun's 1903 book) but also a non-monstrous, flower-like, meter-long stalked crinoid at the left. Illustration by W. Smith. 


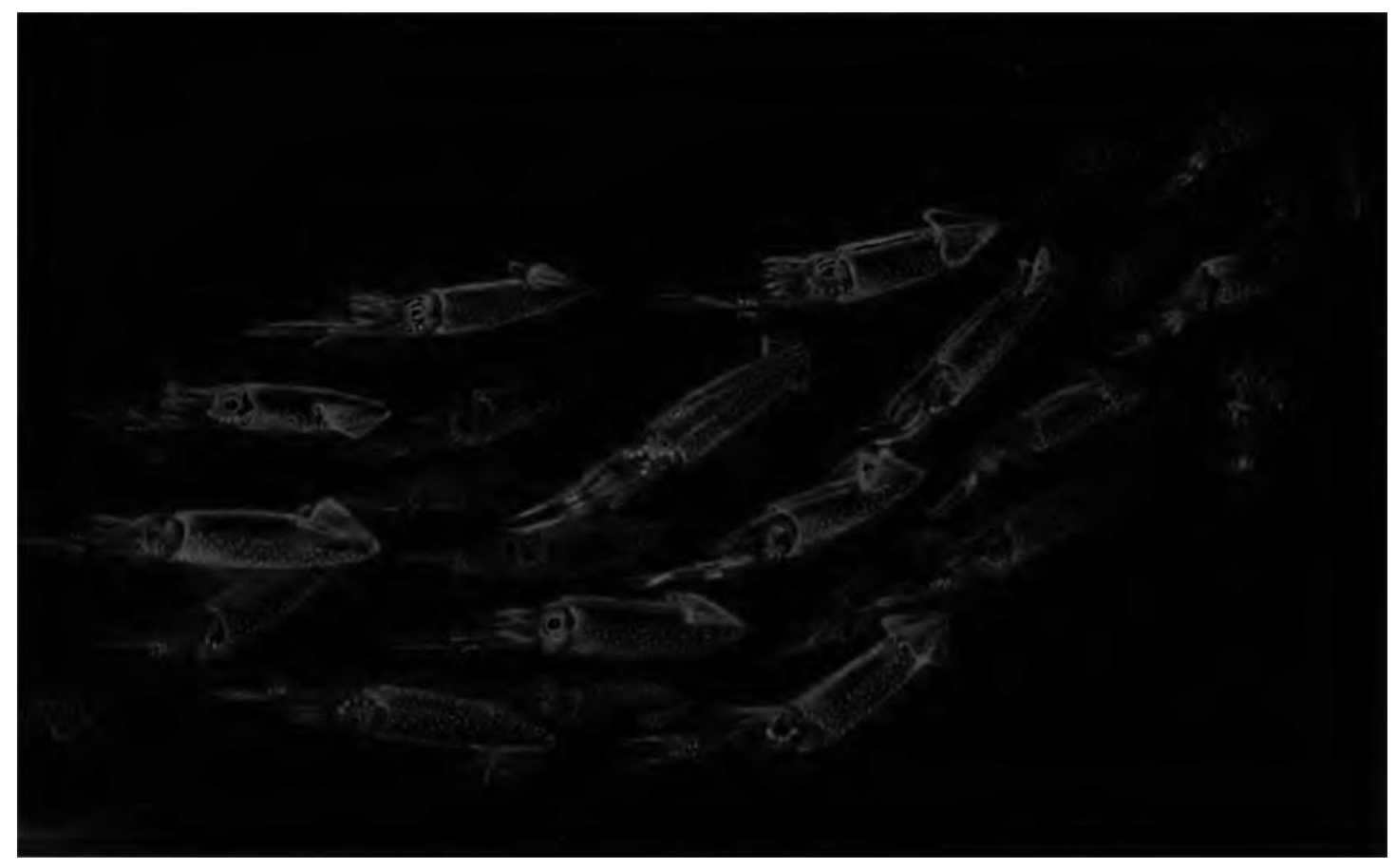

1922. Bioluminescence in deep-sea squids from an article by Dahlgren (1922) on light production by plants and animals in Natural History Magazine. The squid are non-threatening, not all deep-sea creatures depicted were fearsome. Illustration by E. Grace.

PLATE VIII
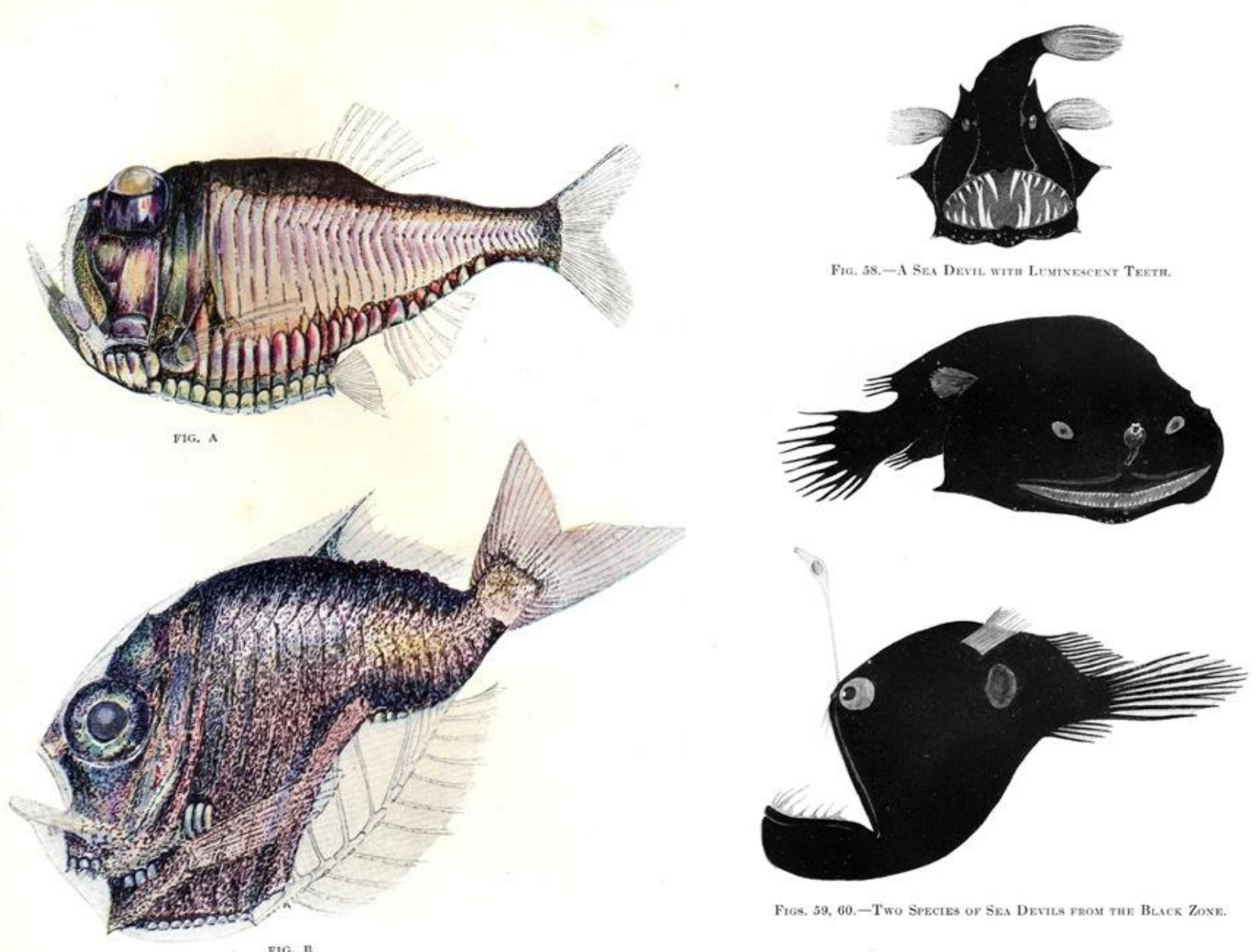
1926. Left Panel: The first illustration, the frontispiece, in William Beebe's book "The Arcturus Adventure", an account of a 6-month oceanographic expedition in 1924 focused on deep-water sampling. Illustration by H. Tee-Van. Note that the hachetfish, shown also by Chun in his 1903 book and Murray \& Hjorts's 1912 book, while quite odd are not threatening. Right Panel: One of the last illustrations in William Beebe's book, the anglerfish shown were found in deep water about 125 Km off New York in the deep-sea Hudson River Canyon. Ferocious fish, one with a diabolical smile, were still prominent. Illustration by D. Franklin.

\section{Modern Period Views (1928 - Present Day): Beyond Deep-Sea Ferocity - Depictions of Natural History}

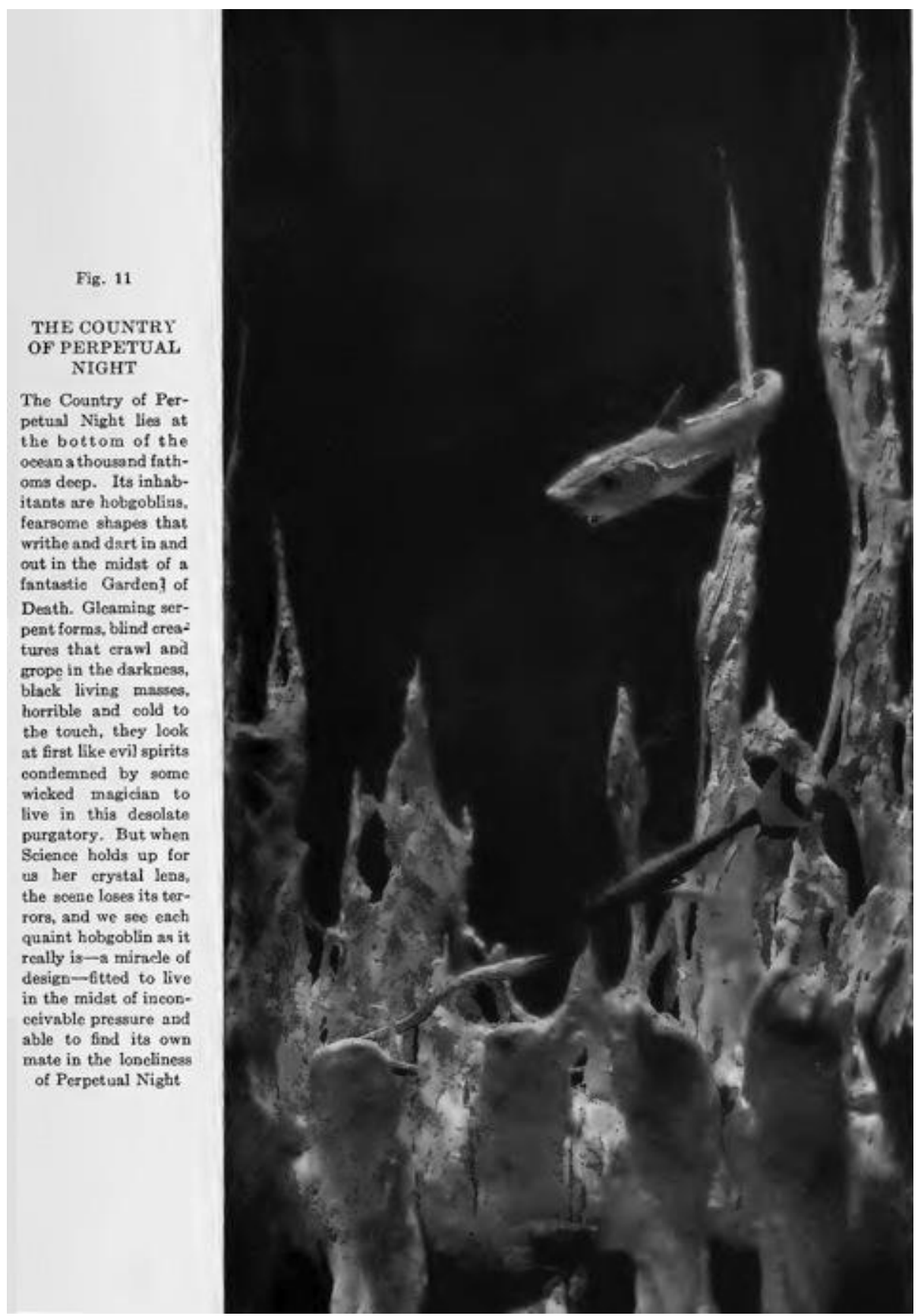

1928. "The Country of Perpetual Night", a picture of a deep-sea diorama showing fish swimming about a whale skeleton. From Gregory (1928), an article in Natural History Magazine on the new fish exhibition hall in the American Museum of Natural History. The caption emphasizes that science has revealed that the odd morphologies of deep-sea fish are simply adaptations to live in the 'Perpetual Night'. 


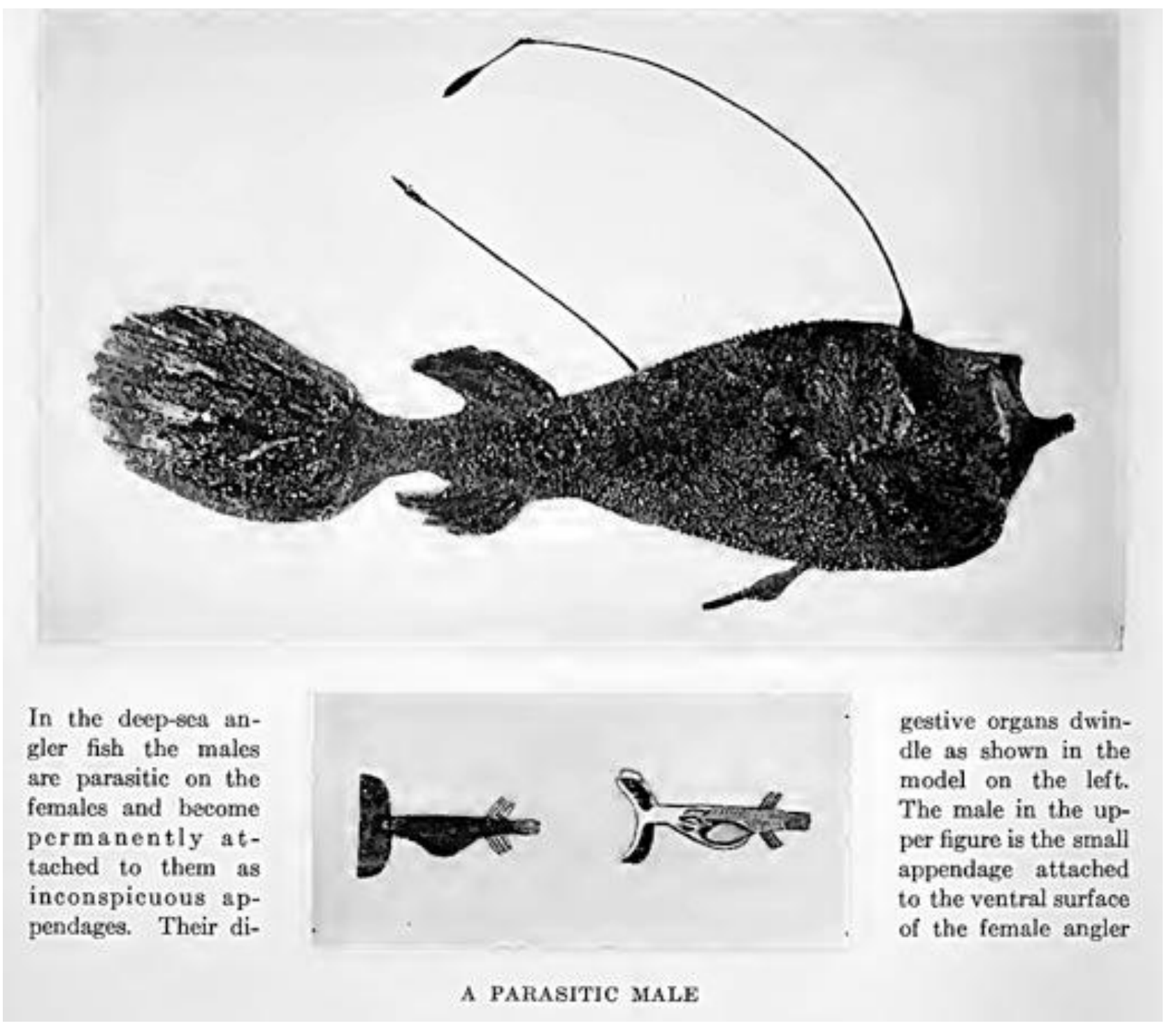

1930. Illustration of the very strange life cycle of the deep-sea anglerfish, discovered in a few years earlier by C.T. Regan (1925). The illustration is from an article by C.G. Noble in Natural History Magazine, "Probing Life's Mysteries". The male of the fish species is a very small form that attaches itself to the female and feeds from its blood. The life cycle of the fish is actually much stranger than its morphology. The differences in male and female morphologies of the deep-sea anglerfish are the most extreme example of sexual dimorphism known among all vertebrate animals (Fairbairn 2013). 


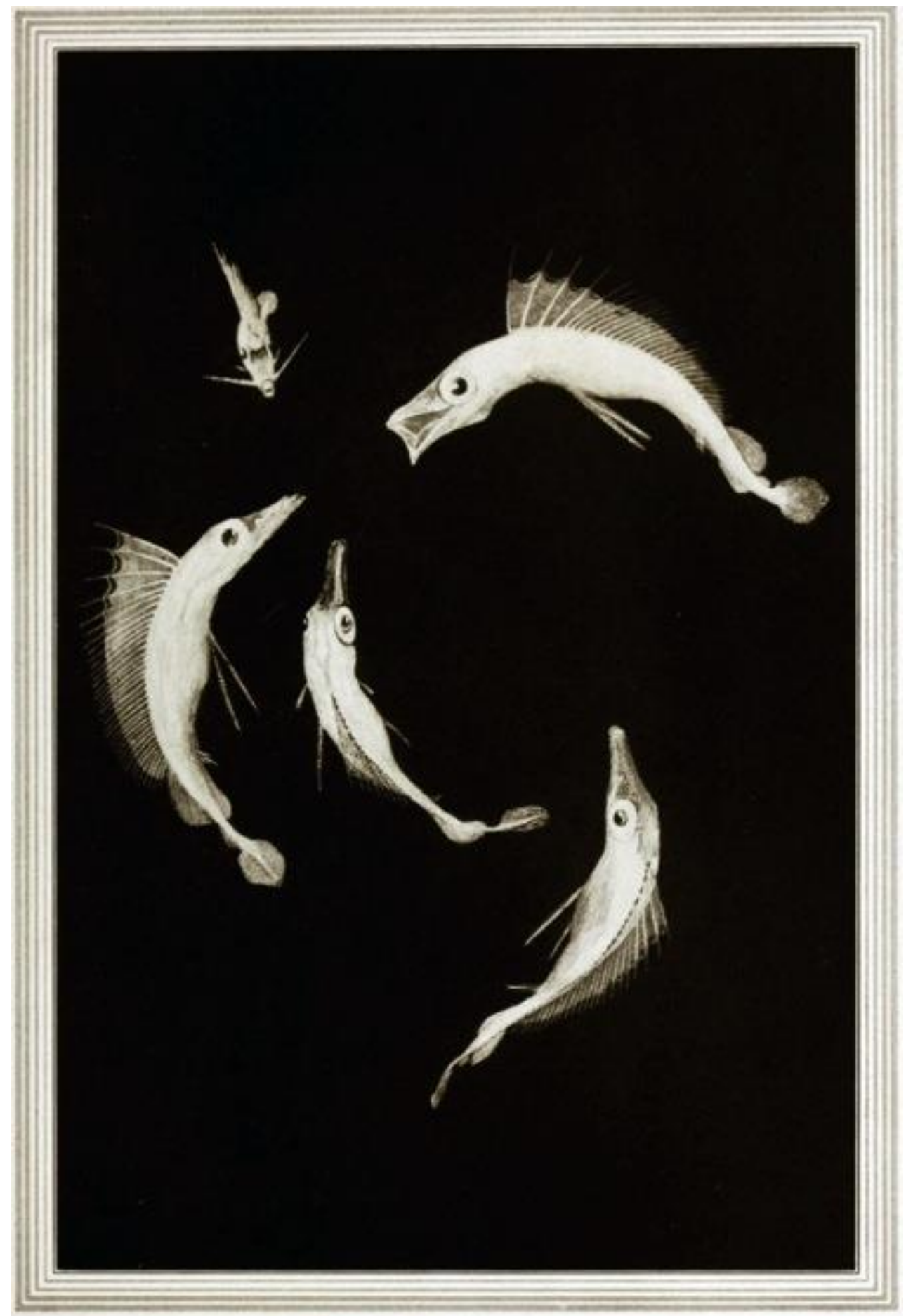

A school of Gerupylids, deep-sea fish whose paired fins have changed into two long spines.

1931. Odd, but non-threatening, deep-sea fish shown by William Beebe in his article in the Annual Report of the New York Zoological Society on his deep sea sampling in Bermuda. Beebe established a field station from which near daily deep-sea sampling was carried out. The Annual Reports were distributed to all the over 4000 members of the Zoological Society of the Bronz Zoo. The 1931 illustration may be the first of a deep-sea fish in the popular press as an appealing, rather than a monstrous, form. Illustration not attributed. 


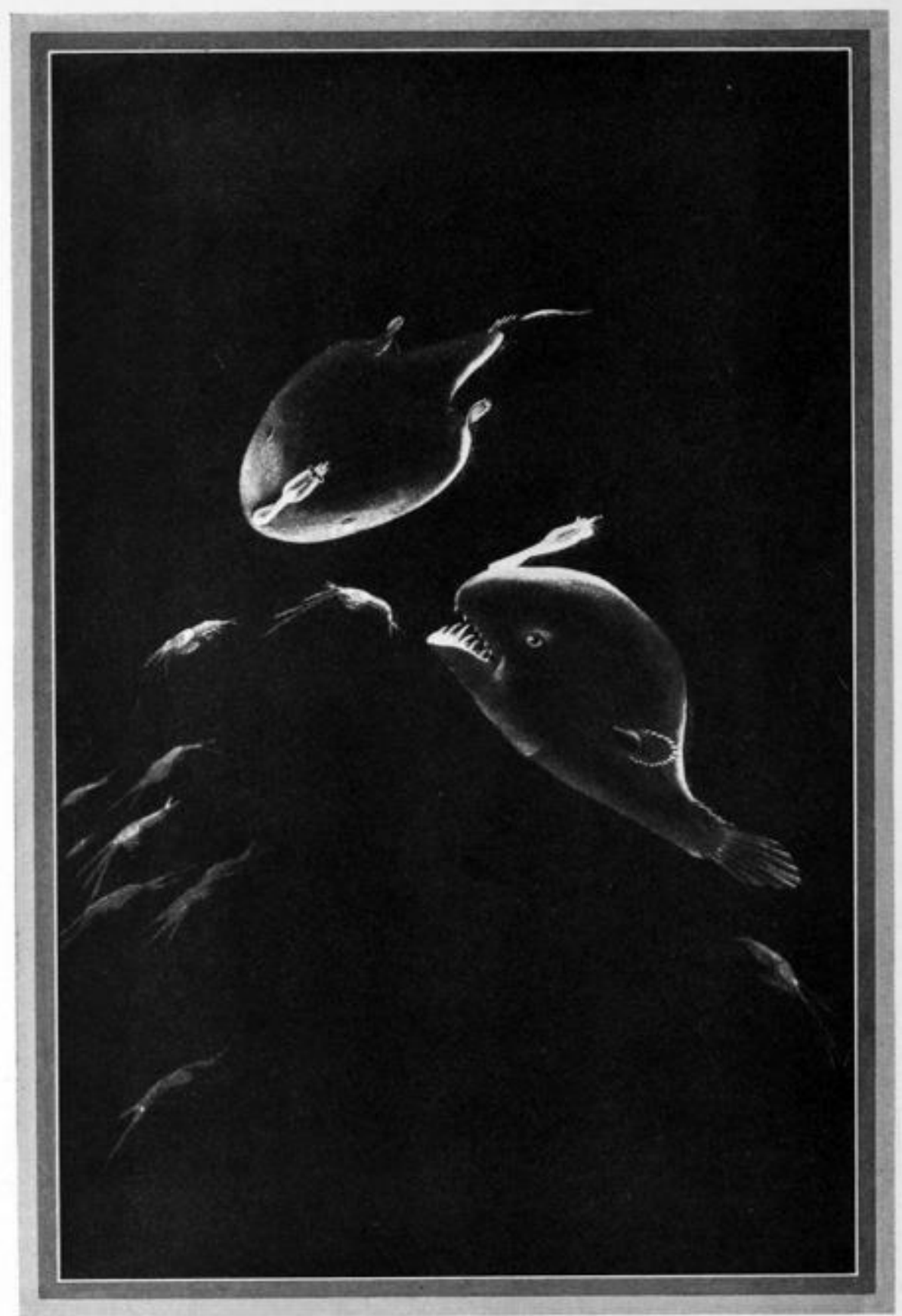

A new species of deep-sea dragonfish, Chaenophryne druco Beebe. Painted by Else Bostelmann

1932. Fierce fish from the cover of the Bulletin of the New York Zoological Society, the Bronz Zoo member's newsletter, in September 1932. Threatening fish were still a popular image but this time shown feeding on squid, not prey larger than themselves, and not as solitary monsters, but a pair. Illustration by E. Bostelman. 


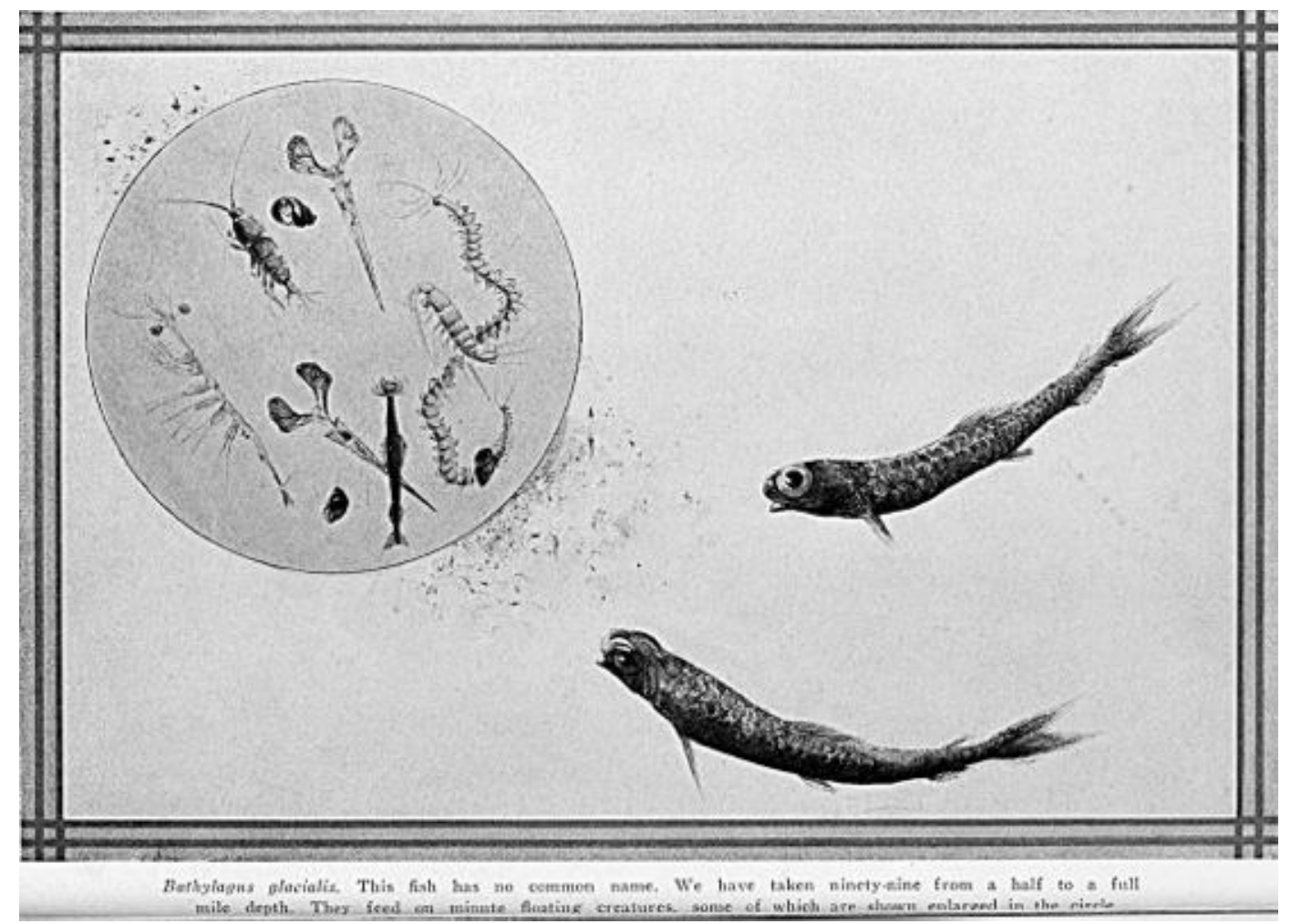

1934. An illustration in Beebe's 1934 article in Annual Report of the Zoological Society showing some deep-sea fish, non-threatening, to be similar in feeding habits to surface water fish, feeding on prey smaller than themselves shown magnified in the circle. Illustration not attributed.

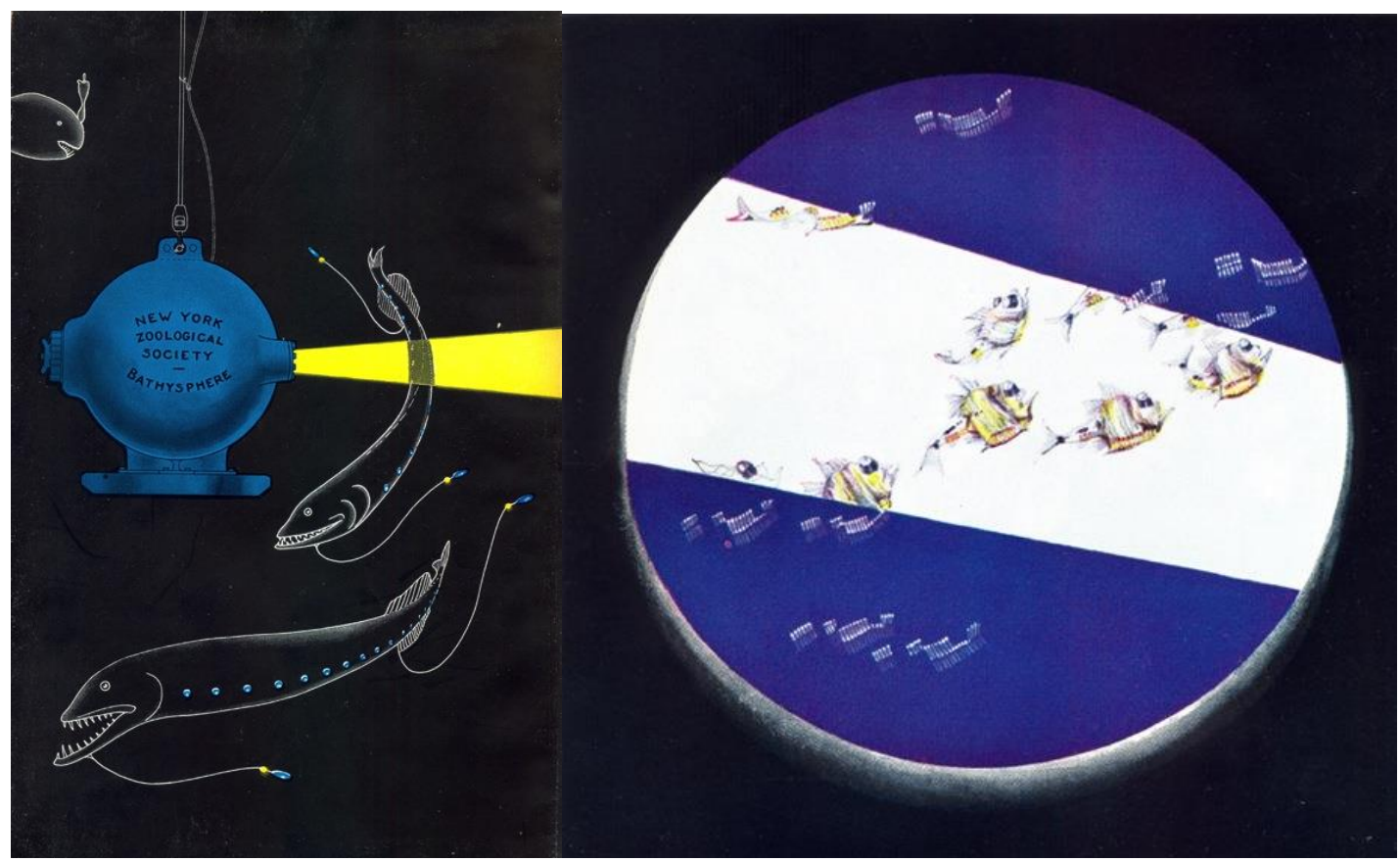

1934. Left Panel: The inside back cover illustration from William Beebe's book "Half Mile Down" on his dives in the bathysphere to observe deep sea creatures, the first in situ observations ever made. Illustration by J. Tee-Van. Right Panel: Plate 1 from Beebe's book, Hachet fish as seen through the porthole of the Bathysphere, crossing the light beam of the Bathysphere's light. Note the harmless, social (schooling) depiction compared to the hachetfish images in the 1903 plate of Chun or the 1912 plate of Murray \& Hjort. Illustration by E. Bostelman. 


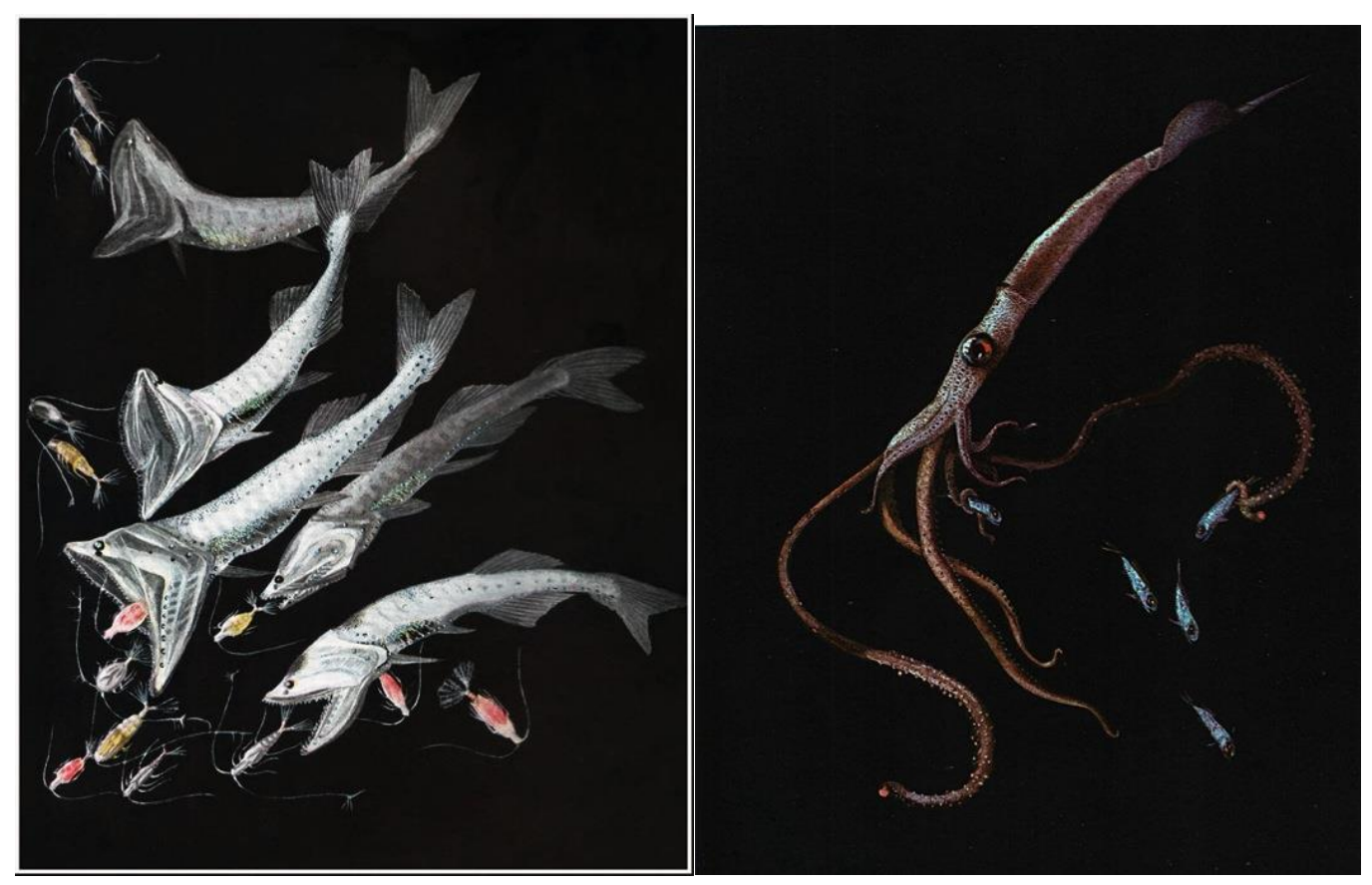

1934. Beebe's "Half-Mile Down" book had illustrations showing predator-prey relationships in the deep based on his observations. Again, social scenes as schools of fish are shown, as predators in the left panel, and as prey in the right panel. Illustrations by E. Bostelman.

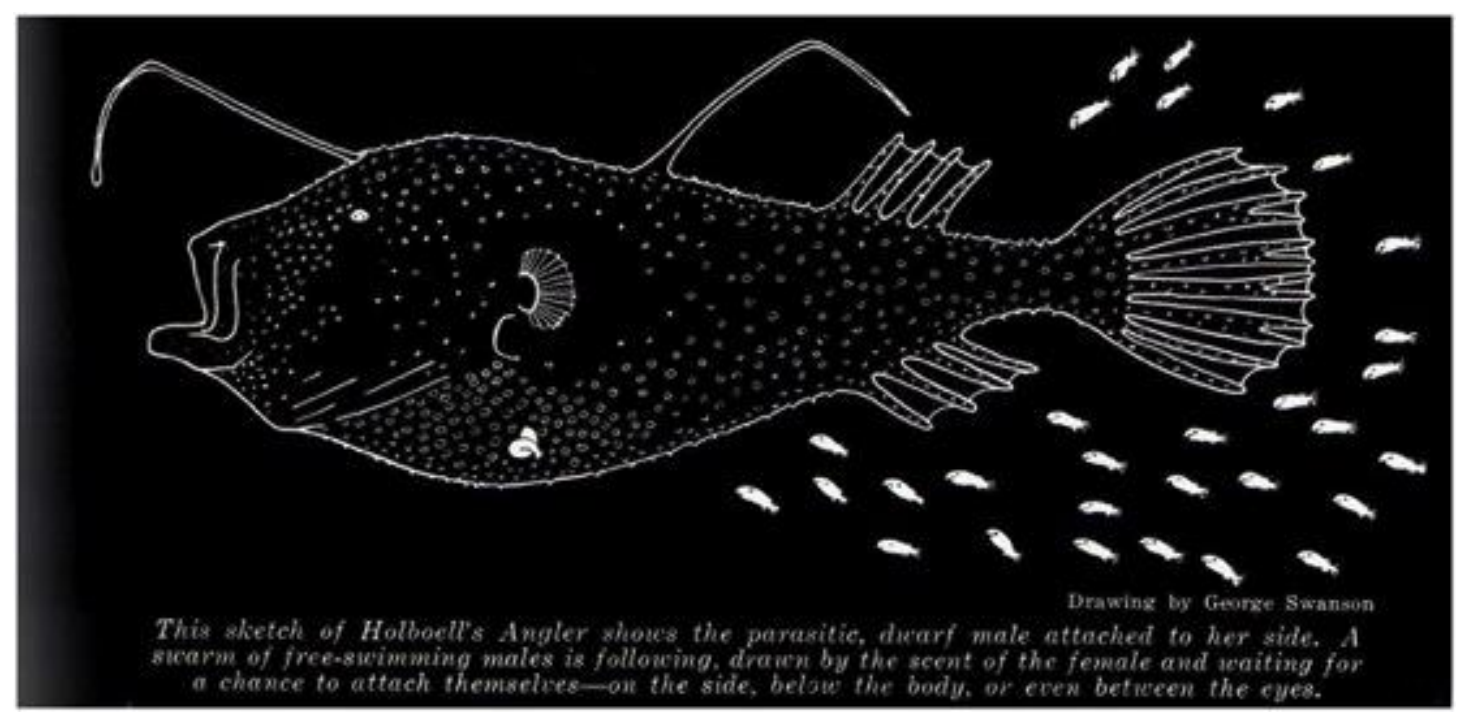

1938. From Beebe's last popular article (1938) in New York Zoological Society Bulletin on a deep-sea species concerned its life cycle - showing the remarkable sexual dimorphism and male parasitism in deep-sea anglerfish in a cartoon-like fashion. A school of dwarf males are shown headed toward the female. The species is the same as that shown in the 1930 article in Natural History magazine. The bizarre secret lives of deep-sea fish were revealed to the public in a nearly comical fashion. Illustration by G. Swanson. 


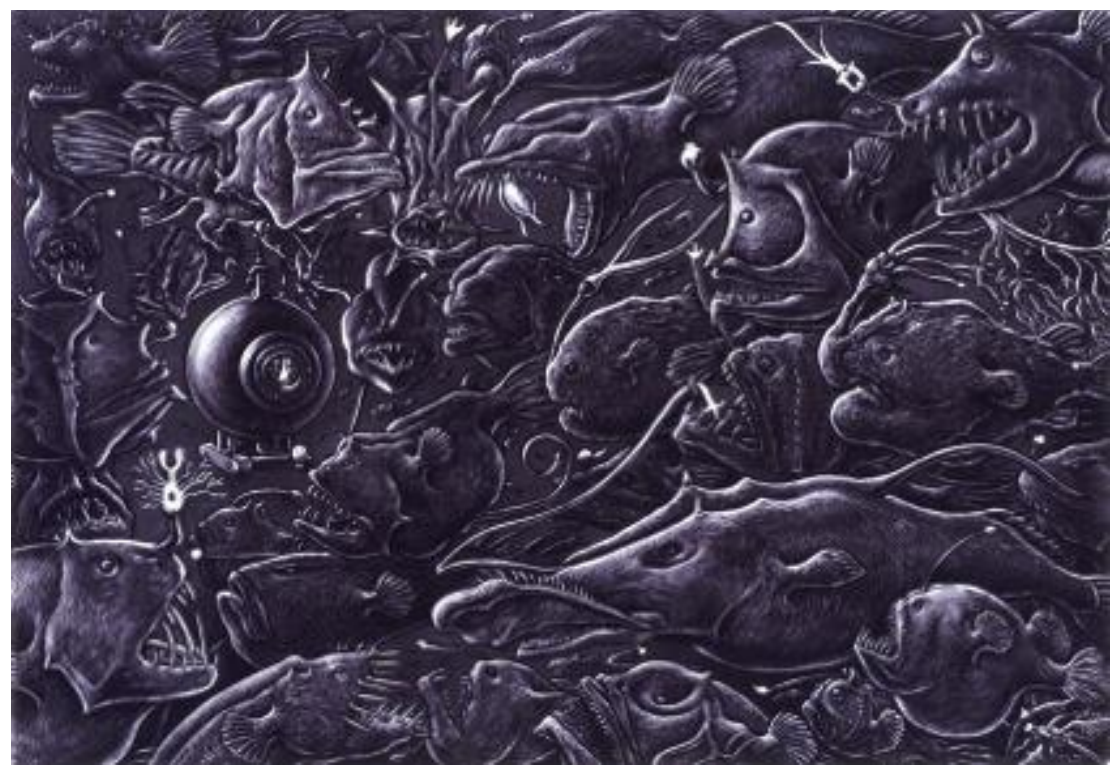

2009. Cover art from the book "Oceanic Anglerfishes: Extraordinary Diversity in the Deep Sea" by Pietsch (2009). Beebe's bathysphere is shown descending into a monstrous sea of anglerfishes much like that shown in Filhol's 1885 "La Vie au Fonds des Mers". Artwork by Ray Troll (C) 2008, courtesy of Ted Pietsch.

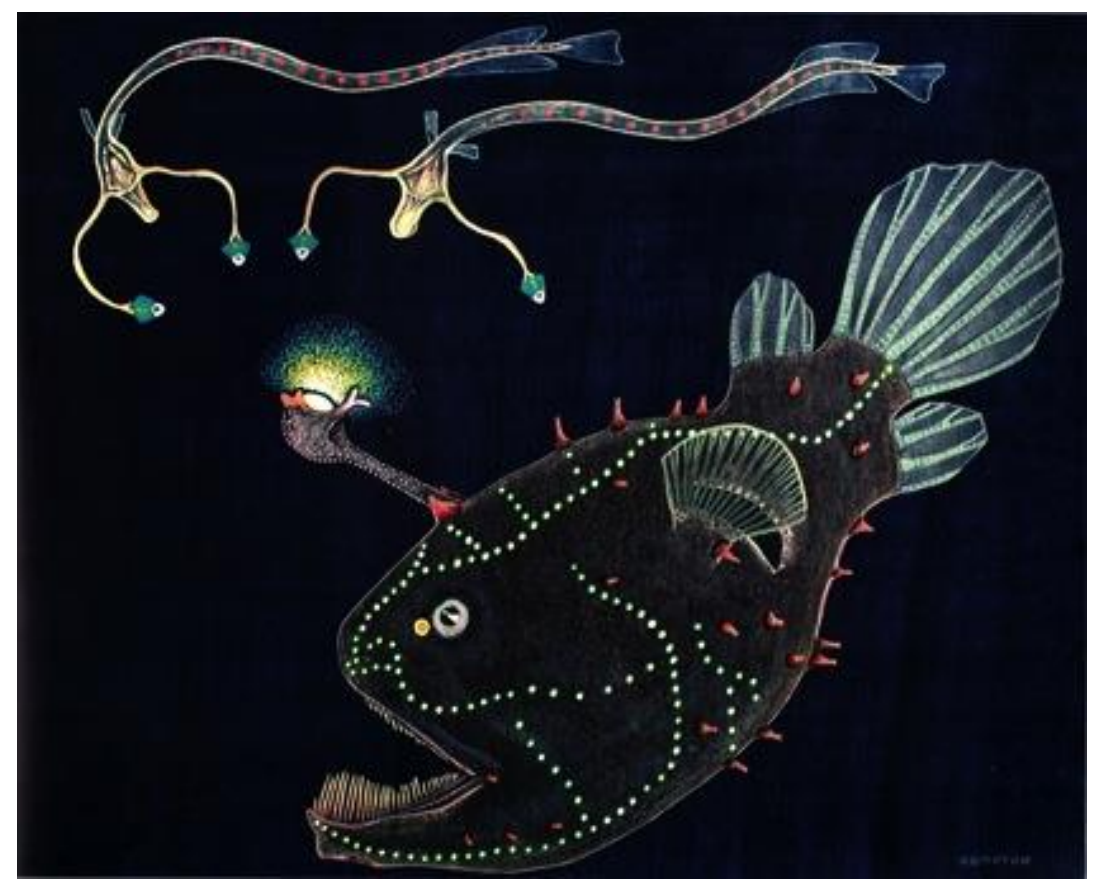

2014. A painting by Henry Compton. From "Fire in the Sea: Bioluminescence \& Henry Compton's Art of the Deep" by David A. McKee, courtesy of Texas A\&M University Press, College Station, Texas, USA (www.tamupress.com). Note that the monstrous stalk-eyed fish larvae, (shown by Chun in 1903, Moffet in 1915 and Thomson in 1922), appear to be attracted to the lighted lure of the anglerfish. The stalk-eyed form was found by Beebe (1933) to be no more than a larval form of a normal-looking, cigar-shaped fish, another example of a strange life cycle in deep-sea forms. 


\section{Conclusion}

Our visions of life in the deep dark sea changed dramatically from 19th to the 20th century. In the popular imagination, the inhabitants changed from giant ship-eating cephalopods to ferocious, longfanged fish in eerie landscapes. The change was due to scientific explorations of the deep-sea revealing the odd inhabitants of the deep. The explorations also changed a scientific view of the deep-sea from that of a life-less zone to that of a biome of surprising diversity of species with odd morphologies and unusual life histories. Work in recent decades has revealed the deep sea to be peppered with zones of hydrothermal vents inhabited by a unique fauna of amazing worms and bivalves, dependent on symbiotic bacteria, in turn fueled by the hydrothermal vents (e.g., Van Dover 1997). Nonetheless, it seems that the most popular visions of deep-sea life remain the monstrous forms of strange fish!

\section{References}

Alcock, A. 1902. A Naturalist in Indian Seas or, four years with the Royal Indian Marine Survey Ship "Investigator". London: John Murray, 486 pp.

Anon 1900. Five miles under water. San Francisco Chronicle, November 11 1900, pg. 32.

Bailey, H. S. 1953. The Voyage of the" Challenger". Scientific American, 188:88-95.

Beebe, W. 1926. The Arcturus Adventure. New York: G.P. Putnam's Sons, 439 pp.

Beebe, W. 1931. Report of the director, department of tropical research. New York Zoological Society Thirty-fifth Annual Report, pp. 89-94

Beebe, W. 1932. New York Zoological Society Bulletin 35, no. 5, cover illustration

Beebe, W. 1933. New data on the deep sea fish Stylophthalmus and Idiacanthus. Science. 78:390

Beebe, W. 1934. New York Zoological Society Thirty-Eighth Annual Report, pp 75-79.

Beebe, W. Half Mile Down. New York: Harcourt Brace and Co., 456 pp.

Beebe, W. 1938. Ceratius-siren of the deep. New York Zoological Society Bulletin 41:50-53.

Bullen, F.T. 1904. Denizens of the Deep. New York: Fleming H. Revell Co., 488 pp.

Chun, C. 1903 Aus den Tiefen des Weltmeeres. Jena: Verlag von Gustav Fischer, 592 pp.

Cornish, C.J. 1904. Living lamps on land and sea. Strand Magazine 28:720-727.

Denys de Montfort, P. 1802. "Histoire naturelle, générale et particulière des mollusques, animaux sans vertèbres et à sang blanc. Ouvrage faisant suite aux Ouvres de Leclerc de Buffon, et partie du Cours complet d'Histoire naturelle rédigé par C. S. Sonnini", tome 2, Paris: De l'Imprimerie de F. Dufart, 424 pp

Dahlgren, U. Phosphorescent animals and plants. Natural History Magazine, 22:5-26.

Filhol, H. 1885. "La Vie au Fonds des Mers. Les explorations sous-marines et les voyages du Travailleur et du Talisman". Paris: G. Masson

Fairbairn, D.J. 2013. "Odd Couples: Extraordinary differences between the sexes in the animal kingdom". Princeton (NJ USA): Princeton University Press, 300 pp

Fredol, A. 1865. "Le monde de la mer". Paris: Masson, 623 pp.

Forbes, E., 1844. Report on the Mollusca and Radiata of the Aegean Sea, and on their distribution, considered as bearing on geology. Rep. Br. Assoc. Adv. Sci.. Cork. 1843. pp. 130-193.

Gregory, W.K. 1928. A tour of the new hall of fishes. Natural History Magazine 28:3-17.

Hatcher, P., Battey, N. 2011, "Biological Diversity: Exploiters and Exploited". Hoboken (NJ USA): Wiley-Blackwell, $436 \mathrm{pp}$

Hickson, S.J. 1894. The Fauna of the Deep Sea. London: Kegan Paul, Trench, Trüber \& Co., 198 pp. 
Mangin, A. 1868 "Les Mystéres de l'Océan". Tours: Alfred Mame et Fils, Editeurs, 496 pp.

McKee, D.A. 2014. "Fire in the Sea: Bioluminescence \& Henry Compton's art of the deep". Corpus Christ (TX USA): Texas A \& M University Press, 184 pp

Milne-Edwards, A. 1861. Observations sur l'existence de divers Mollusques et Zoo-phytes à de très grandes profondeurs dans la mer Méditerranée.- Annales des Sciences Naturelles, Zoologie, Paris, (4ème série), vol. 15, p. 149-157.

Moffet, C. 1915. Living wonders of the deep sea. The Strand Magazine 50:92-98.

Murray, J., Hjort, J. 1912. The Depths of the Ocean: A general account of the modern science of oceanography based largely on the scientific researches of the Norwegian steamer Michael Sars in the North Atlantic. London: Macmillian and Co. $880 \mathrm{pp}$

Noble, G.K., 1930. Probing life's mysteries. Natural History Magazine, 30:469-482.

Pietsch, T.W. 2009. Oceanic Anglerfishes: Extraordinary Diversity in the Deep Sea. Berkeley: University of California Press, 557 pp

Regan, C. T. 1925. Dwarfed males parasitic on the females in oceanic angler-fishes (Pediculati Ceratioidea). Proceedings of the Royal Society of London. Series B, 97:386-400.

Rehbock, P.F. 1975. Huxely, Haeckel, and the oceanographers: the case of Bathybius haeckelii. Isis 66:504-533.

Rice, A. L. 1980. The beginning of French Oceanography- the cruise of the Travailleur, July 1880. Oceanologica Acta 1: 266-266.

Thompson, C.W. 1873. The Depths of the Sea. An account of the general results of the dredging cruises of H.M.S.S. 'Porcupine' and 'Lightening' during the summers of 1868, 1869, and 1870, under the scientific direction of Dr. Carpenter, F.R.S., J. Gwyn Jeffreys, F.R.S., and Dr. Wyville Thompson, F.R.S.. London: MacMillian and Co., 626 pp.

Thompson, W.C. 1877. The Voyage of the 'Challenger.' The Atlantic, A preliminary account of the general results of the exploring voyage of H.M.S. 'Challenger' during the year 1873 and the early part of the year 1876. In Two Volumes. London: Macmillian and Co., vol 1461 pp, vol 2340 pp

Thomson, J.A. 1922. The Haunts of Life. New york: Harcourt, Brace and Co., 317 pp

Townsend, C.H. 1902. The life of the deep sea. Everybody's Magazine 6:115-130.

Van Dover, C.L. 1997. Deep Ocean Journeys: Discovering new life at the bottom of the sea. Cambridge (MA USA): Perseus Publishing, 204 pp

Verne, J. 1869. "Vingt Mille Lieues sous les mers". Paris: Pierre-Jules Hetzel, 436 pp

Wallich, G.C. 1862. The North-Atlantic Sea-Bed Comprising a Diary of the Voyage on board H.M.S. Bulldog, in 1860; and observations on the presence of animal life, and the formation and nature of organic deposits, at great depths in the ocean. London: John Van Voorst, 184 pp. 